\title{
Late Holocene onset of intensive cultivation and introduction of the falaj irrigation system in the Salut oasis (Sultanate of Oman)
}

Article

Accepted Version

Cremaschi, M., Esposti, M. D., Fleitmann, D., Perego, A., Sibilia, E. and Zerboni, A. (2018) Late Holocene onset of intensive cultivation and introduction of the falaj irrigation system in the Salut oasis (Sultanate of Oman). Quaternary Science Reviews, 200. pp. 123-140. ISSN 0277-3791 doi: https://doi.org/10.1016/j.quascirev.2018.09.029 Available at https://centaur.reading.ac.uk/79711/

It is advisable to refer to the publisher's version if you intend to cite from the work. See Guidance on citing.

To link to this article DOI: http://dx.doi.org/10.1016/j.quascirev.2018.09.029

Publisher: Elsevier

All outputs in CentAUR are protected by Intellectual Property Rights law, including copyright law. Copyright and IPR is retained by the creators or other copyright holders. Terms and conditions for use of this material are defined in the End User Agreement. 


\section{www.reading.ac.uk/centaur}

\section{CentAUR}

Central Archive at the University of Reading

Reading's research outputs online 


\section{Late Holocene onset of intensive} cultivation and introduction of the falaj irrigation system in the Salut oasis (Sultanate of Oman)

Article

Cremaschi, M., Esposti, M. D., Fleitmann, D., Perego, A., Sibilia, E. and Zerboni, A. (2018) Late Holocene onset of intensive cultivation and introduction of the falaj irrigation system in the Salut oasis (Sultanate of Oman). Quaternary Science Reviews, 200. pp. 123-140. ISSN 0277-3791 doi: https://doi.org/10.1016/j.quascirev.2018.09.029 Available at http://centaur.reading.ac.uk/80017/

It is advisable to refer to the publisher's version if you intend to cite from the work.

To link to this article DOI: http://dx.doi.org/10.1016/j.quascirev.2018.09.029

Publisher: Elsevier

All outputs in CentAUR are protected by Intellectual Property Rights law, including copyright law. Copyright and IPR is retained by the creators or other copyright holders. Terms and conditions for use of this material are defined in the End User Agreement. 
www.reading.ac.uk/centaur

\section{CentAUR}

Central Archive at the University of Reading

Reading's research outputs online 


\section{Late Holocene onset of intensive cultivation and introduction of the falaj irrigation system in the Salut oasis (Sultanate of Oman)}

Mauro Cremaschi ${ }^{1}$, Michele Degli Esposti², Dominik Fleitmann ${ }^{3}$, Alessandro Perego ${ }^{1}$, Emanuela Sibilia ${ }^{4}$, Andrea Zerboni ${ }^{1, *}$

1) Dipartimento di Scienze delle Terra "A. Desio", Università degli Studi di Milano, Via L. Mangiagalli 34, I-20133 Milano, Italy

2) Associated member, UMR 6566 - CReAAH, Centre de Recherche en Archéologie, Archéosciences, Histoire

3) Department of Archaeology and Centre for Past Climate Change, School of Human and Environmental Sciences, University of Reading, Reading, UK

4) Dipartimento di Scienze dei Materiali, Università degli Studi Milano-Bicocca, Via R. Cozzi 55, I20125 Milano, Italy

*Corresponding author: Tel.: +39.02.50315292; Fax: +39.02.50315494; E-mail: andrea.zerboni@unimi.it

\section{Abstract}

This paper discusses the time and steps of the introduction of intensive agriculture and evolution of irrigation systems to sustain crops in the palaeo-oasis of Salut in the northern Sultanate of Oman. Various geoarchaeological methods allow reconstructing the exploitation of the natural resources of the region and technological development of irrigation methods since the MidHolocene. Intensive agriculture started during the Bronze Age and continued with some spatial and intensity fluctuations up to the Islamic period. Cultivations were initially sustained by surface irrigation systems and later replaced by a dense net of aflaj, the typical surface/underground system adopted in the Levant, Arabian Peninsula and western Asia to collect water from deep piedmont aquifers and redistribute it to the fields located in the lowlands. Our results indicate that the aflaj were in use for a long period in the palaeo-oasis formed along Wadi Sayfam and surrounding the citadel of Salut. Uranium-Thorium dating of calcareous tufa formed in the underground tunnels of the aflaj suggests that they were used between $\sim 540$ BCE and $\sim 150$ CE. After 1150 CE Wadi Sayfam were abandoned and the size of the oasis shrank substantially. During the late Islamic period, a surface aqueduct descending from the piedmont of Jabal Shams 
secured water supply. Our work confirms that in arid lands archaeological and historical communities were able to actively modulate their response to climate changes by using a variety of technological strategies.

Keywords: Cultivation in ancient oasis; Irrigation strategies; Falaj; U-series dating; Climate change; Mid-Late Holocene; Northern Oman. 


\section{Introduction}

If one considers Holocene archaeological evidences in arid and semi-arid lands, it emerges that water availability is one key-factor for societal development. There is a number of archaeological examples from the Sahara, the Arabian Peninsula and Thar Desert that reveal human responses to abrupt changes in water availability (and subsequent effects on the landscape) during the Holocene (e.g. Weiss, 1997; Brooks, 2006; Cremaschi et al., 2006; Madella and Fuller, 2006; Cremaschi and Zerboni, 2009; Manning and Timpson, 2014; Desruelles et al., 2016; Zerboni et al., 2016). Most of examples date back to the mid-Late Holocene (e.g., Mayewski et al., 2004; Anderson et al., 2007), when the progressive weakening of the summer monsoon led to the progressive reduction of water reservoirs throughout the subtropical desert belt (e.g., Fleitmann et al., 2007). Communities, whose subsistence was mainly based on agriculture and pastoralism, tried to adapt to the increasing aridity (e.g., Kuper and Kropelin, 2006; Zerboni et al., 2016). In regions with high population density, communities attempted to increase agriculture productivity by introducing technologies for water harvesting and management. The technological apogee of this process was reached by the spread of irrigation systems (qanat and falaj) across Persia, the Levant, the Arabian Peninsula, and later into Africa (Lightfoot, 2000).

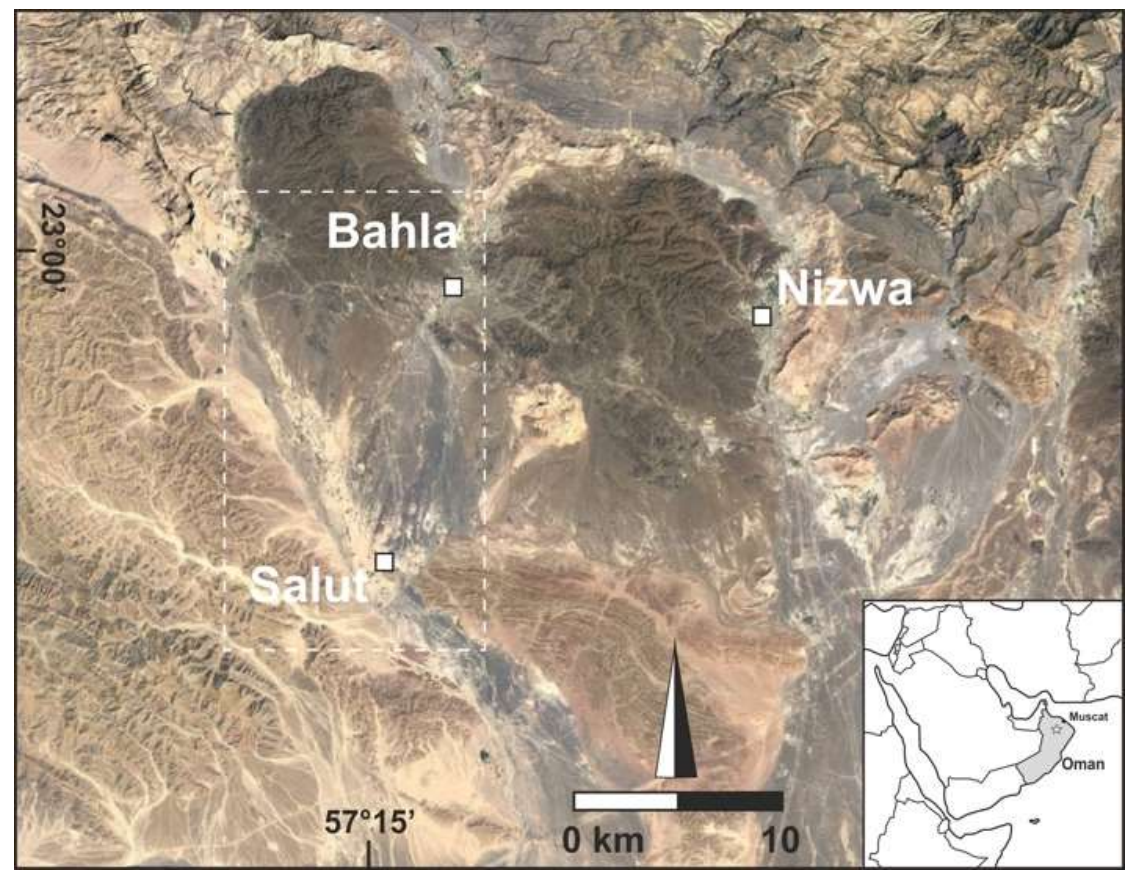

Fig. 1. Satellite imagery (Google Earth ${ }^{\mathrm{TM}}$ ) of the study site between the cities of Bahla, Nizwa and Salut; the dashed box indicates the area of map of Fig. 3. The inset illustrates the position of the study region in the Sultanate of Oman. 
In the semi-arid northern Sultanate of Oman (Fig. 1) the landscape preserves evidence of agricultural activity dating back at least to the Bronze Age (e.g. Cleuziou and Costantini, 1980; Potts, 1994a, 1994b; al-Jahwari, 2009) and irrigation facilities were likely established in the area of Bat in the late $3^{\text {rd }}$ millennium BCE (Desruelles et al., 2016). In the region surrounding the ancient citadel of Salut, a recent geoarchaeological survey revealed a complex archaeological landscape, which includes settlements dating back to the Neolithic, the Bronze Age, the Iron Age, and the Islamic period (Humphries, 1974; Avanzini and Phillips, 2010; Avanzini, 2015; Degli Esposti et al.,

2018b). Furthermore, the survey revealed a complex network of irrigation facilities, comprising of irrigation ditches connected to canals and aflaj (Fig. 2), some of are still being used today. This evidence suggests an oasis that was considerable larger than the present one. Our research in the area of Salut focused on the irrigation facilities (Fig. 3) in order to date the aflaj system, determine their use during the late Holocene and regional climatic changes. This was achieved by Uraniumseries dating $\left({ }^{230} \mathrm{Th}\right.$ hereinafter) the calcareous tufa from the underground parts of the irrigation system. The ${ }^{230} \mathrm{Th}$ dates reveal that the local aflaj system was constructed in the last centuries BCE. Furthermore, there is strong evidence that the aflaj systems were not continuously used and reactivated in Islamic times.

\section{Irrigation technologies in the Sultanate of Oman}

In sub-tropical arid regions, the problem of bringing water from the piedmont aquifers to arid and semi-arid valleys, plains, and lowlands has been faced almost in the same way. Qanats in Iran, Syria, Jordan, Saudi Arabia, and Spain (Lightfoot, 1996, 1997, 2000; Stiros, 2006; Bailiff et al., 2015), foggaras, in the Sahara, from Egypt to Algeria (Barker et al., 1996; Mattingly, 2003; Lightfoot, 2000), ghayl or miyan in Yemen (Lightfoot, 2000), karez in Pakistan (Khan and Nawaz, 1987), and falaj (plural aflaj, Al-Marshudi, 2007) in the United Arab Emirates and in the Sultanate of Oman (e.g. Alsharhan et al., 2001; Jorgensen and Al-Tikiriti, 2002; Al-Marshudi, 2007; Siebert et al., 2007; Remmington, 2018) are different local names for gravity-driven filtration galleries constructed for irrigation (Fig. 2). They consist of a subsurface aqueduct collecting groundwater from a mother well, sunk into an aquifer (Lightfoot, 2000). Groundwater infiltrating into the wells is transported by gravity through a gently sloping tunnel to a main canal and distribution point (shari'a) from where minor ditches then diverge to bring water to the fields. The great relevance of such irrigation structures for farming in marginal regions is evident, as suggested by the fact that some are still in use . 


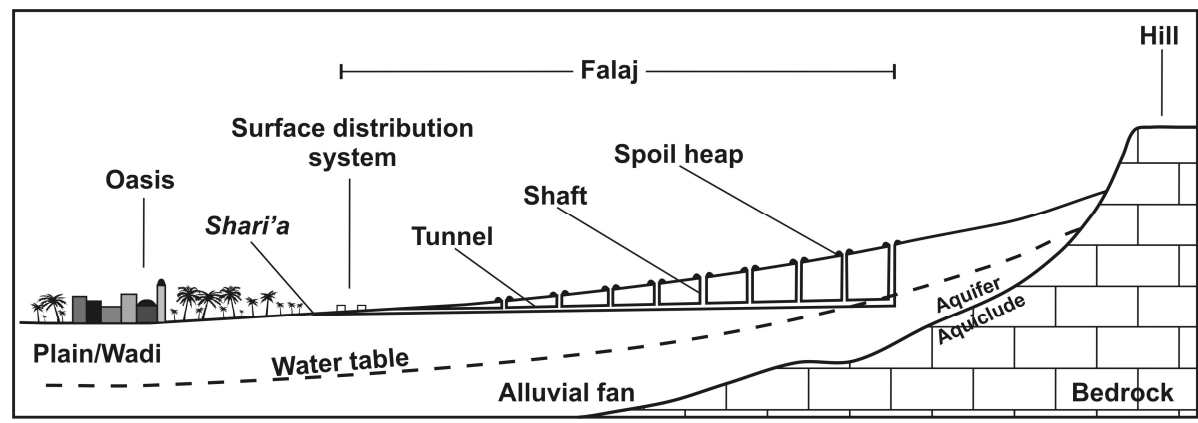

Fig. 2. A theoretical model representing the falaj irrigation system.

In Oman, the age of aflaj systems is still debated and mainly based on inductive arguments and historical written sources, whereas only a few estimates are based on absolute radiometric dates (Clark and Fontes, 1990). While there has long been a general belief that this irrigation technology was introduced to the Sultanate of Oman by the Persians after 600 BCE (Wilkinson, 1977, 1983), new archaeological evidence suggest an earlier introduction of aflaj in the region at the beginning of the $1^{\text {st }}$ millennium BCE (Al Tikriti, 2002, 2010; Charbonnier, 2015). The hypothesis of an even earlier use already during the Early Bronze Age (late $4^{\text {th }}$ millennium BCE), proposed by Orchard and Orchard (2010) on the basis of weak archaeological evidence must be so far regarded as speculative in the absence of robust radiometric dates. In the area of Salut, the introduction of aflaj was attributed to the $1^{\text {st }}$ millennia BCE (Iron Age) on the basis of the concomitance with the substantial coeval archaeological context (Avanzini et al., 2005). Three types of falaj are distinguished in Oman: (i) dawoudi falaj taps water from deep underground aquifers usually located in piedmont areas; (ii) ghayl falaj conversely exploits shallow water tables from alluvial fans (Wilkinson, 1977; Boucharlat, 2003); (iii) aini falaj, directly derives its water from springs (Al Sulaimani et al., 2007). So far, only ghayl falaj have been connected to an ancient (Iron Age) use in southeast Arabia (Boucharlat, 2003). 


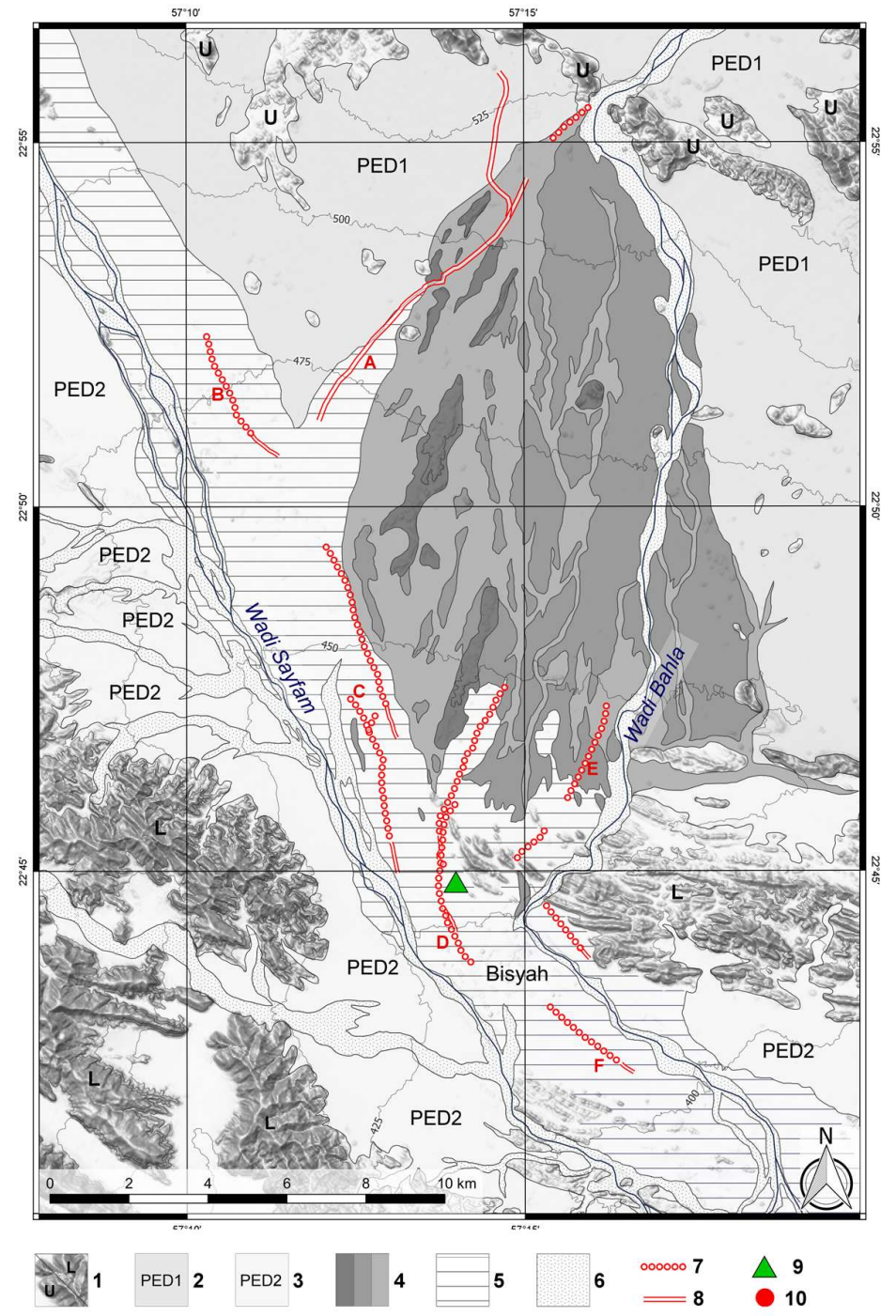

Fig. 3. Simplified geomorphological map of the region, indicating the main geomorphological units, archaeological structures related to water management (falaj, canals, ditches, settlements); the position of the citadel of Salut is also represented. Key: 1) bedrock ( $U$ is ultrabasic rocks, $L$ are deep-oceanic sediments of mainly radiolarian chert and limestone); 2) pediment at the margin of the ultrabasic rocks (PED1); 3) pediment at the base of the sedimentary formations (PED2); 4) alluvial fans of wadi Bahla of different ages; 5) alluvial plain of wadi Sayfam (Khabra Formation, gravel and calcrete); 6) recent deposits of the wadi bed; 7) aflaj; 8) canals; 9) citadel of Salut; 10) Salut ruins of Islamic age, as reported in the available topographic maps; A) Canal Jabrin; B) Falaj Salut; C) Falaj Shaww and Falaj Farud; D) Falaj Bisyah; E) Falaj Hayl 1 and 2; F) Falaj Azabi.

\section{Geological setting, climate and Late Holocene palaeoclimate of the area}

The study site is located in northern Oman (Fig. 1) between the modern villages of Bisya (2 km to the South) and Bahla (20 km to the North), and is delimited to the West by Wadi Sayfam and to the 
East by Wadi Bahla (Fig. 3). At present, the region is characterized by an arid savannah, with palm groves and some cultivated fields where water is pumped from deep wells. However, in the area has been used for intensive agriculture, as shown by the dense network of inactive ditches that crosses the fields. The bedrock in this region consists of a variety of sedimentary and igneous rocks (Geologic Map of Oman, 1.250,000, sheet NF4007 - NIZWA). The area is delimited to the North by the relief being part of the Mid-Late Cretaceous Samail Ophiolite (tectonized harzburgite and intrusive peridotite and gabbro), and to the West and to the South by Permian to Cretaceous sedimentary formations (limestone and radiolarite formations). Pleistocene and Holocene deposits cover part of the region, including large alluvial fans and fine sediments covering most of the bottom of the alluvial plain along the main wadis. The latter is recorded by the geological map as Khabra Formation, but its origin and age have been disclosed by this work (see section 6.1.).

The present climate of the Northern Oman is arid to semi-arid and influenced by the annual migration of the ITCZ (Intertropical Convergence Zone) and seasonal development of the monsoon winds. Rainfall originates from Mediterranean frontal systems in winter and spring, local thunderstorms in summer and tropical cyclones that reach the region every 5-10 years (Weyhenmeyer et al., 2000, 2002). Annual rainfall varies between 150 and $250 \mathrm{~mm} \mathrm{yr}^{-1}$ (Alsharhan et al., 2001; Fleitmann et al., 2007) and potential evapotranspiration is $2600 \mathrm{~mm} \mathrm{yr}^{-1}$ (FAO, 1987).

Palaeoclimate studies based on speleothems from the Hoti Cave, some $45 \mathrm{~km}$ from the citadel of Salut, elucidate the Holocene changes in precipitation occurred in northern Oman in close detail (Neff et al., 2001; Fleitmann et al., 2007). According to oxygen isotope $\left(\delta^{18} \mathrm{O}\right)$ profiles covering the early Holocene (between $10.5-9.5 \mathrm{ka} \mathrm{BP}$ ), the mean latitudinal position of the summer ITCZ and the associated Indian Summer Monsoon (ISM) rainfall belt advanced northward, leading to a substantial increase in precipitation. After $\sim 7.8 \mathrm{ka}$ BP to present, the mean summer ITCZ continuously migrated southward and the intensity and duration of the ISM season decreased gradually. Several abrupt and short-lived climatic events occurred and were superimposed on a general long-term gradual aridification trend as revealed by stalagmite Q5 from Southern Oman (Fleitmann et al., 2003). Because of its geographical position, the total amount of ISM precipitation decreased abruptly at around $6.2 \mathrm{ka}$ BP in northern Oman (Fleitmann et al., 2007) as the position of the summer ITCZ and the associated ISM rainfall belt was located south of Hoti Cave. For the $2^{\text {nd }}$ and $1^{\text {st }}$ millennium BCE that is the time of the intensive exploitation of the Salut oasis, no direct palaeohydrological information is available sue to a temporal gap in the speleothem record from the Hoti Cave (Fleitmann et al., 2007). A marked decrease in 
precipitation is however registered at ca. 2 ka BP. Speleothems from southern Oman and Socotra (Yemen) also confirm a general decrease in intensity of the Indian Ocean monsoon in the late Holocene (Fleitmann et al., 2007).

\section{The archaeology of the area of Salut}

The wealth of archaeological remains of the study area was first highlighted in 1973 by the Harvard Archaeological Survey (Humphries, 1974; Hastings et al., 1975), followed slightly later by a British Archaeological Expedition (de Cardi et al., 1976). Although other archaeological investigations were conducted in the area (Orchard and Orchard, 2002), most of them remained unpublished, specifically concerning survey data useful for the diachronic reconstruction of settlement patterns. Starting in 2004, the work of the Italian Mission to Oman included excavations at key sites (Husn Salut; Salut-ST1; Jabal Salut necropolis; Qaryat Salut) as well as surveys of the surrounding area, the results of which can be used to outline the evolution of human occupation as a background against which water management can be studied (Degli Esposti, 2015). 


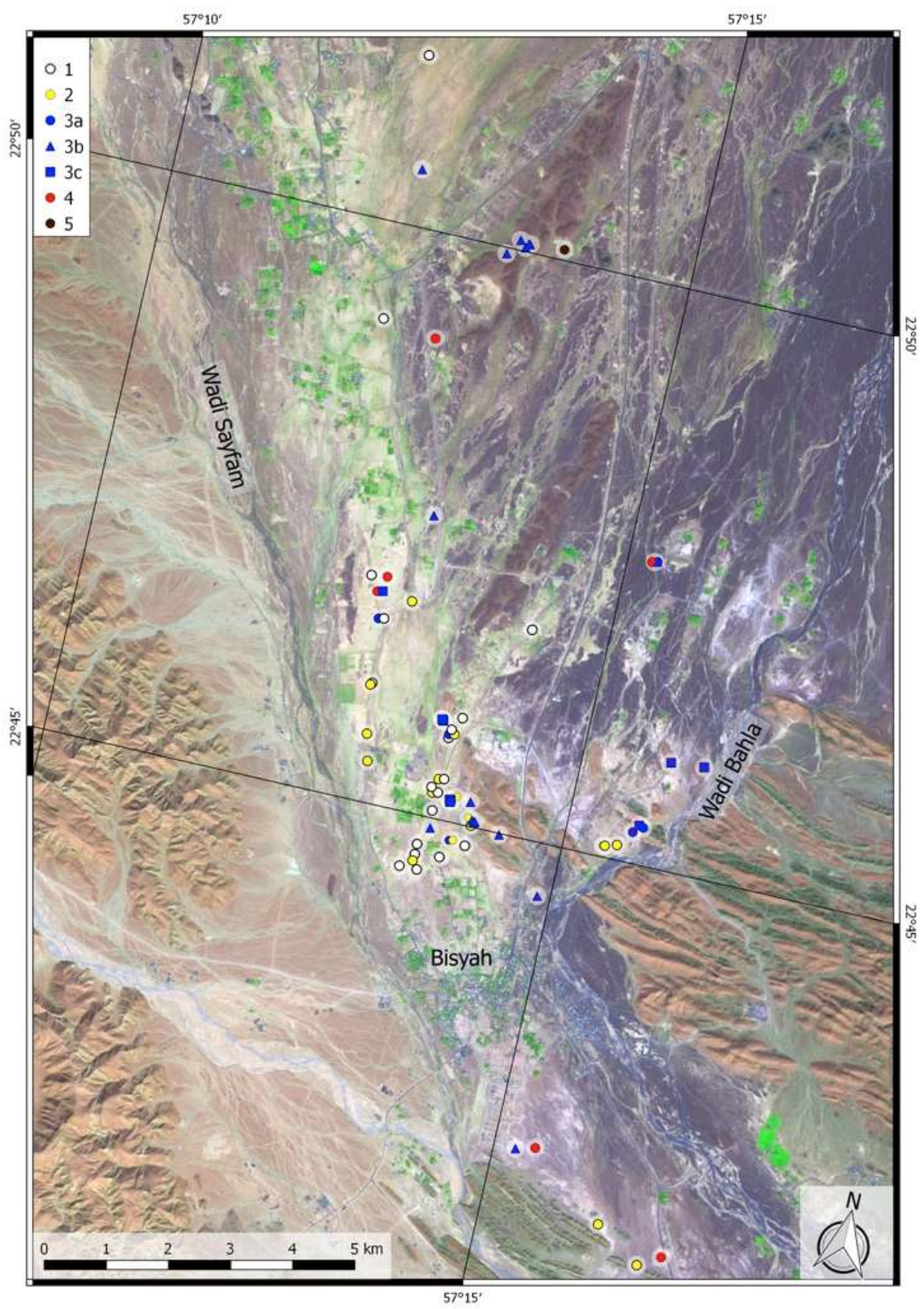

Fig. 4. Distribution of the main archaeological sites in the study region. Key: 1) Islamic Age sites; 2) Iron Age sites; 3a) Bronze Age sites; 3b) Bronze Age cairns; 3c) Bronze Age towers; 4) Neolithic sites; 5) Palaeolithic sites.

The earliest human traces in the area can be dated back to the Palaeolithic as indicated by artefacts found on the gravelly terraces West of Wadi Bahla (Fig. 4). An account for the Neolithic period is given by several scatters of lithic industries, in most cases recorded in association with surviving accumulations of the Khabra Formation. However, the first floruit of the area corresponds to the local Early Bronze Age (also referred to as the Umm an Nar period dated to the second half of the $3^{\text {rd }}$ millennium $B C E$ ), when at least three monumental stone tower sites were 
erected along the eastern side of Wadi Sayfam's plain, pairing an even larger system established along the lower reaches of Wadi Bahla (Orchard and Stanger, 1994; Degli Esposti, 2016). Countless, contemporary tombs are scattered all over the surrounding hills.

The first half of the $2^{\text {nd }}$ millennium BCE apparently coincides with a remarkable demographic decrease, interrupted at the end of the $15^{\text {th }}$ century BCE at the latest by the establishment of a dense network of Iron Age sites, clustering around the citadel of Salut with its surrounding village, at least two of which occupy an entire small hillock (Avanzini and Phillips, 2010; Phillips et al., 2010; Condoluci et al., 2014). Recent investigation indicates a duration of this settlement, although possibly not of all the smaller sites, until the Late Iron Age period, between 650 and 300 BCE, if not even longer as it is likely the case for Salut itself (Degli Esposti et al., 2018a). It is during this long period that the palaeo-oasis likely reached its greatest spatial extent, and consequently provided subsistence for a large population.

After $\sim 300 \mathrm{BCE}$, the archaeological record indicates a very long phase, during which the Salut plain lay abandoned for more than one millennium. In fact, on the hill of Salut itself three distinct periods of Islamic occupation are witnessed by the collected pottery, the first dated around the $9^{\text {th }} / 10^{\text {th }}$ century CE (Early Islamic), the second around the $12^{\text {th }} / 13^{\text {th }}$ century CE (Middle Islamic), and the third after the $16^{\text {th }}$ century CE (Late Islamic) (Whitcomb 1975; Avanzini et al., 2005; Avanzini and Degli Esposti, 2018), although structural remains only mirror two major building phases (Avanzini and Degli Esposti, 2018). During this long period, the Salut palaeo-oasis was occupied again as indicated by the wide scatters of Islamic pottery collected contextually to archaeological evidence of irrigation.

\section{Methods}

In order to investigate the origin and development of irrigated agriculture in the oasis of Salut we chose a geoarchaeological approach, aiming to put together the geologic and archaeological evidence, and then to compare them with the Mid-Late Holocene climate changes occurred in Northern Oman as recently discussed on the basis of several palaeohydrological archives for proxy data (e.g., Fleitmann et al., 2007).

The geomorphology of the area together with the distribution of the aflaj and archaeological sites has been mapped using geological maps, remote sensing and fieldwork. Remote sensing desk studies (performed with the QGIS 2.14 software) used high-resolution Sentinel-1A imagery; the image used for the geomorphological map is a false colour composition 
of bands 2, 8, and 12. Elevation data were obtained processing a Global Digital Surface Model ALOS World 3D, 30m of ground resolution (AW3D30). Furthermore, an intensive geoarchaeological survey of the area has been carried out to locate archaeological sites, identify and sample soils and sediments for studying the Holocene climatic changes. Twenty-one trenches have also been opened around the citadel of Salut, to investigate mid- to late-Holocene sediment sequences. From the stratigraphic sequence of some of the trenches, oriented and undisturbed blocks have been extracted for micromorphological analysis to identify the stratigraphic sequenceforming processes and infer the environmental and anthropogenic factors for sedimentation and post-depositional changes (Courty et al., 1989; Goldberg and Macphail, 2006; Goldberg and Berna, 2010). Thin sections $(5 \times 9 \mathrm{~cm})$ were manufactured after consolidation according to the methods described by Murphy (1986). Micromorphological observation under plane-polarized light (PPL) and cross-polarized light (XPL) of thin sections employed an optical petrographic microscope Olympus BX41 with a digital camera (Olympus E420). The description and interpretation of thin sections followed the terminology and concepts established by Bullock et al. (1985), Stoops (2003), and Stoops et al. (2010). Thin sections $(3 \times 5$ and $5 \times 9 \mathrm{~cm})$ of several samples of calcareous tufa were also observed under the petrographic microscope, and several gold-coated samples were observed with a Cambridge 360 Scanning Electron Microscope (SEM); this helped in interpreting their formation in arid environments (see: Pentecost, 2005; Cremaschi et al., 2010; Nicoll and Sallam, 2017).

Uranium-series dating and stable isotope (carbon and oxygen) analysis were performed on calcium carbonate concretions at the Institute of Geological Sciences, University of Bern. Sampled specimens of carbonate concretions were cut parallel to their growth axis using a diamond saw and then polished; single laminae were drilled for dating, while continuous transects were milled for isotope determinations. Seven Uranium-series ages were performed with a multi-collector inductively coupled plasma mass spectrometer (MC ICP-MS). For MC ICP-MS analyses, 0.1-0.2 g of each sample has been drilled, and analysed according to the procedure described by Fleitmann et al. (2007). Ages were calculated on half-lives of Cheng et al. (2000) and are reported in years before present (BP). Where necessary, ages were corrected for initial detrital ${ }^{230} \mathrm{Th}$ under the assumption of a ${ }^{230} \mathrm{Th} / 232 \mathrm{Th}$ activity ratio analogous to the average crust (Wedepohl, 1995). For each carbon and oxygen isotope analysis, $0.3 \mathrm{mg}$ of powder was obtained from the samples at $0.3 \mathrm{~mm}$ intervals, and analysed with a Finnigan Delta V Advantage mass spectrometer equipped with an automated carbonate preparation system (Gas Bench-II). All isotopes values are reported in parts 
per mil (\%) relative to the Vienna PeeDee Belemnite standard (VPDB). Further details on the Uranium-series dating method and stable isotope analysis are provided by Fleitmann et al. (2007).

Supplementary data to reconstruct the chronological framework of irrigation in the region consist of a single accelerator mass spectrometry radiocarbon $\left(\mathrm{AMS}-{ }^{14} \mathrm{C}\right.$ ) dating on a sample of massive and highly porous calcareous tufa and a thermoluminescence dating on a fragment of pottery collected below the spoil heap of a falaj. AMS- ${ }^{14} \mathrm{C}$ age result was calibrated using the INTCAL13 calibration curve (Reimer et al., 2013). A single fragment of pottery found in a buried soil was dated by Thermoluminescence (Aitken, 1985), using the standard fine-grain technique (Multiple Additive Dose protocol for dose evaluation and direct measurement of the radioactivity concentrations of both sample and burial soil).

\section{Results}

\subsection{Geomorphology of the area}

From the geomorphological point of view (Fig. 3), a system of coalescent alluvial fans, parallel to the direction of Wadi Bahla, stretches out from the northern ophiolitic hills, reaching the alluvial plain at the eastern margin of Wadi Sayfam. The fans are gravely in texture and available geological maps attribute them to Pleistocene aggradation phases, whereas the different degrees of rock varnish covering the surface of each fan suggest different stages of evolution of the system, the darkest being the oldest (Oberlander, 1994; Perego et al., 2011). The generations of alluvial fans are distinguished in the geomorphological map (Fig. 3). The fan system, mainly upper Pleistocene in age, incorporates remnants of older, dissected alluvial deposits, consisting of dark-varnished gravel bodies cut by fluvial erosion and surrounded by more recent fluvial units. The occurrence of several scatters of lithics dating to the Palaeolithic (Fig. 4) may indicate at least a Middle/Upper Pleistocene age for their deposition. 


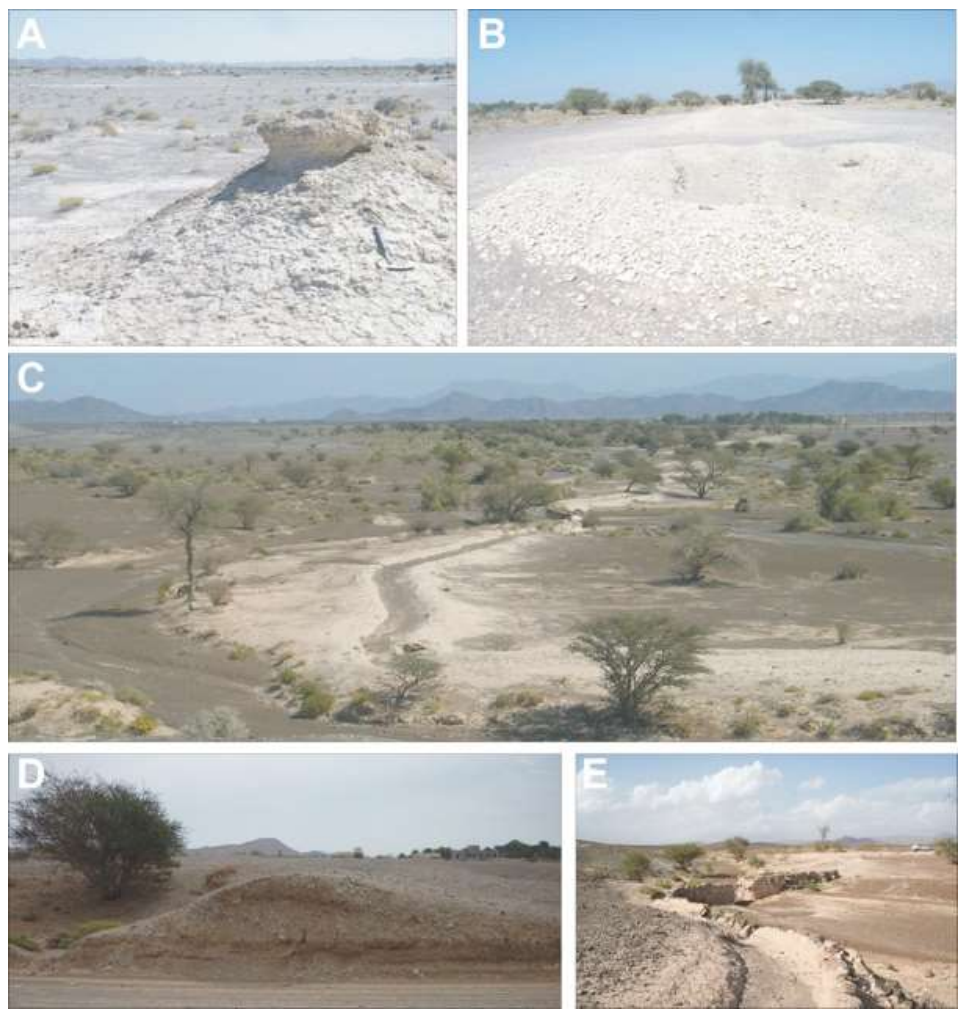

Fig. 5. Pictures of the surveyed area: A) an outcrop of the Khabra Formation along the alluvial plain; B) panoramic view of falaj Shaww, note the alignments of spoil heaps; C) general view of Canal Jabrin; D) the Bw soil horizon preserved below the levee's sediment of Falaj Farud (the trowel indicates the top of the horizon); E) masonry aqueduct along Canal Jabrin.

The surface of the alluvial plain of Wadi Sayfam and Wadi Bahla is mainly covered by thin layers of light brown loam, named Khabra Formation in the geological map (Fig. 5). The formation covers deeply cemented fine sediments and conglomerate (calcrete), which is easily identified on the satellite imagery due to its whitish color, which greatly contrasts with the dark color of the surrounding alluvial fans. The Khabra Formation is often reworked by past human activities and contains Iron Age to Islamic sherds. Yet, fine textured deposits are often interrupted by loose gravel bars, which represent the course of the Wadi Sayfam, occasionally still reactivated. South of Bisya, some outcrops of the Khabra Formation are up to $1 \mathrm{~m}$ thick consist of silt and sand which are pale brown in color, and covered by a slightly cemented carbonate crust. At the base of some outcrops, clusters of Neolithic lithics were found, whereas the alluvial plain is occupied by several archaeological structures dating to the Bronze Age. Our analysis of the Khabra Formation reveals that it consists of wind-blown silt and fine sand (desert loess). The lithic assemblages found mainly at its base suggest that this formation was deposited during the Early Holocene when climatic 
conditions were considerable wetter than today and when the area was covered by bush grassland, which trapped the desert loess brought by northern winds (Cremaschi et al., 2015).

\subsection{The archaeological evidence of the irrigation system in the area of Salut}

An inactive (unused) irrigation system between Bahla and Bisya was probably long since abandoned. The irrigation system consists of ca. $49 \mathrm{~km}$ of mainly aflaj, and interconnected open-air canals, which also appear on the topographic map (Oman 1:100,000, sheet NF40-7A - BAHLA). Fig. 3 shows the distribution of irrigation facilities, mapped against the geomorphological and geological evidence. According to local people, the aflaj ceased definitively to carry any water during the 1970s. Some well shafts were re-excavated and lined with concrete to reach the water table during the 1990s. Moreover, perfectly preserved until few years ago, the aflaj system of Salut is currently endangered by the construction of a modern water pipeline network.

The following features have been mapped and surveyed on the field (Fig. 3, 5, 6). Falaj Salut (total length ca. $700 \mathrm{~m}$ ), Falaj Shaww (total length ca. $4.5 \mathrm{~km}$ ), Falaj Farud (total length ca. 5 km), and Falaj al Hayl 1 and 2 (in total ca. $3 \mathrm{~km}$ long) are located along the valley of Wadi Sayfam, while Falaj Bisya and its eastern bifurcation (ca. 5 and $4 \mathrm{~km}$ long, respectively), and Falaj Azabi (ad-Dhabi - total length ca. $8 \mathrm{~km}$ ) come from the gravelly alluvial fans of Wadi Bahla. At surface, the occurrence of each falaj is revealed by regular alignments of spoil rings (Fig. 5), ca. $12 \mathrm{~m}$ in diameter. They have a height ranging from ca. 0.6 to $1.2 \mathrm{~m}$ and are aligned at regular intervals of ca. $15 \mathrm{~m}$. The sequence of spoil rings of each falaj is most likely incomplete and in some cases the starting point of the falaj (the mother well) and its termination have been obliterated by colluviation, collapse, and recent erosion of the spoil heaps. Furthermore, in many cases the shafts of the aflaj are totally or in part collapsed and their original depths cannot be assessed. Yet, the underground tunnels were accessible only in very few cases, and they do not preserve their original shape due to the collapse of underground structures and shaft walls. 


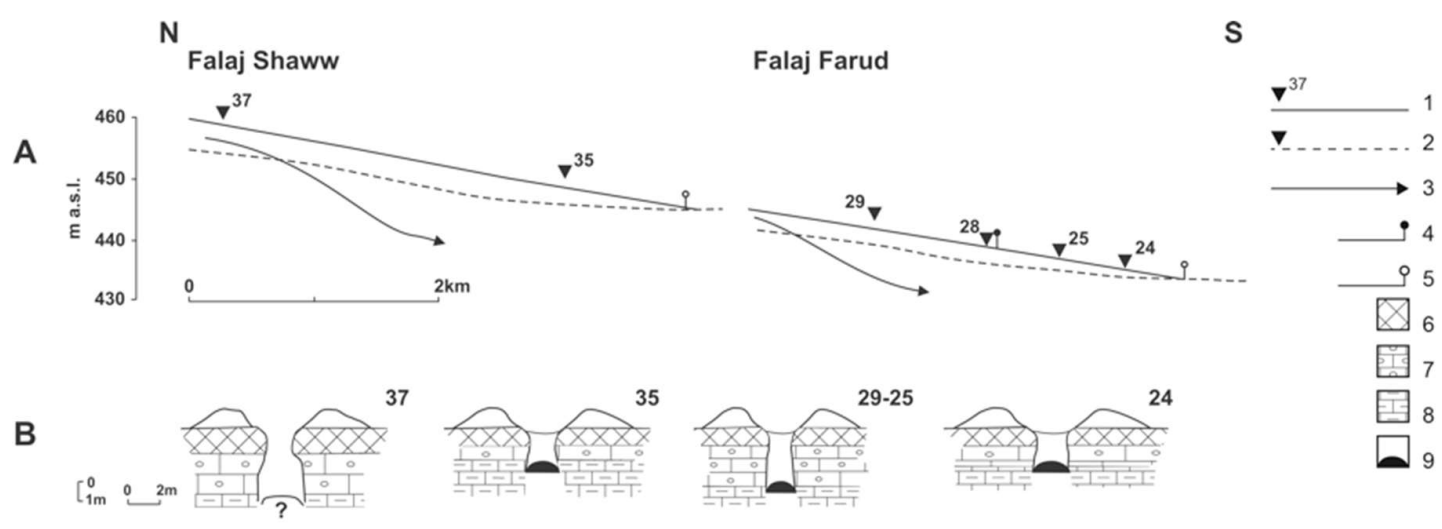

Fig. 6. Falaj Shaww and Falaj Farud profiles (A) and sections (B). Key: 1) topographic surface and location of shafts; 2) underground falaj profile; 3) trend of the water table; 4) extant emergence of the falaj tunnel; 5) former emergence of the falaj tunnel; 6) calcrete; 7) weakly cemented gravel; 8) strongly cemented calcrete in marly bedrock; 9) falaj tunnel.

The sediments cut by the falaj shafts were observed in correspondence to Falaj Shaww, Falaj Farud, and Falaj Bisya. They appear rather homogeneous and consist of 2-3 m of gravel strongly cemented at its top (calcrete), below one metre of reworked silt of the Khabra Formation, and up to $5 \mathrm{~m}$ of gravel (mostly with limestone and ophiolithic pebbles) lying on strongly cemented marls, which discontinuously covers the limestone bedrock. When accessible, the underground tunnels appear to be excavated in the hard cemented calcrete. From a hydrological point of view, the aflaj appear to exploit water from a confined aquifer, consisting of weakly cemented gravel and sand, included between two superposed aquicludes. The latter are composed of deeply cemented pedosediments (calcrete) upon the aquifer and deeply cemented limestone at its bottom.

Based on their state of preservation two main types of aflaj can be distinguished: (i) very degraded aflaj characterized by filled shafts and flat and smooth spoil heap, with deposits that are slightly compacted and homogenized with the surrounding ground (Falaj Hayl 1 and 2, and the upper reach of Falaj Azabi); (ii) better preserved aflaj open shafts, some of which are enlarged by erosion and collapse of the rims, with depths varying between 2 and $12.5 \mathrm{~m}$ (the mother well of the Falaj Bisya) (Avanzini et al., 2005). In the latter case, the spoil heaps are up to $2 \mathrm{~m}$ high, very distinct from the surrounding plain, and consists of loose material (along Falaj Salut, Falaj Shaww, Falaj Farud, and Falaj Bisya). The archaeological survey around the aflaj (Fig. 4) indicates that clusters of Late Islamic pottery fragments are generally in relation with the aflaj of the second group (in the intermediate part of Falaj Farud and along the whole Falaj Bisya). Apart from that, 
archaeological material is generally lacking, as in the case of the deeply eroded aflaj of the first group.
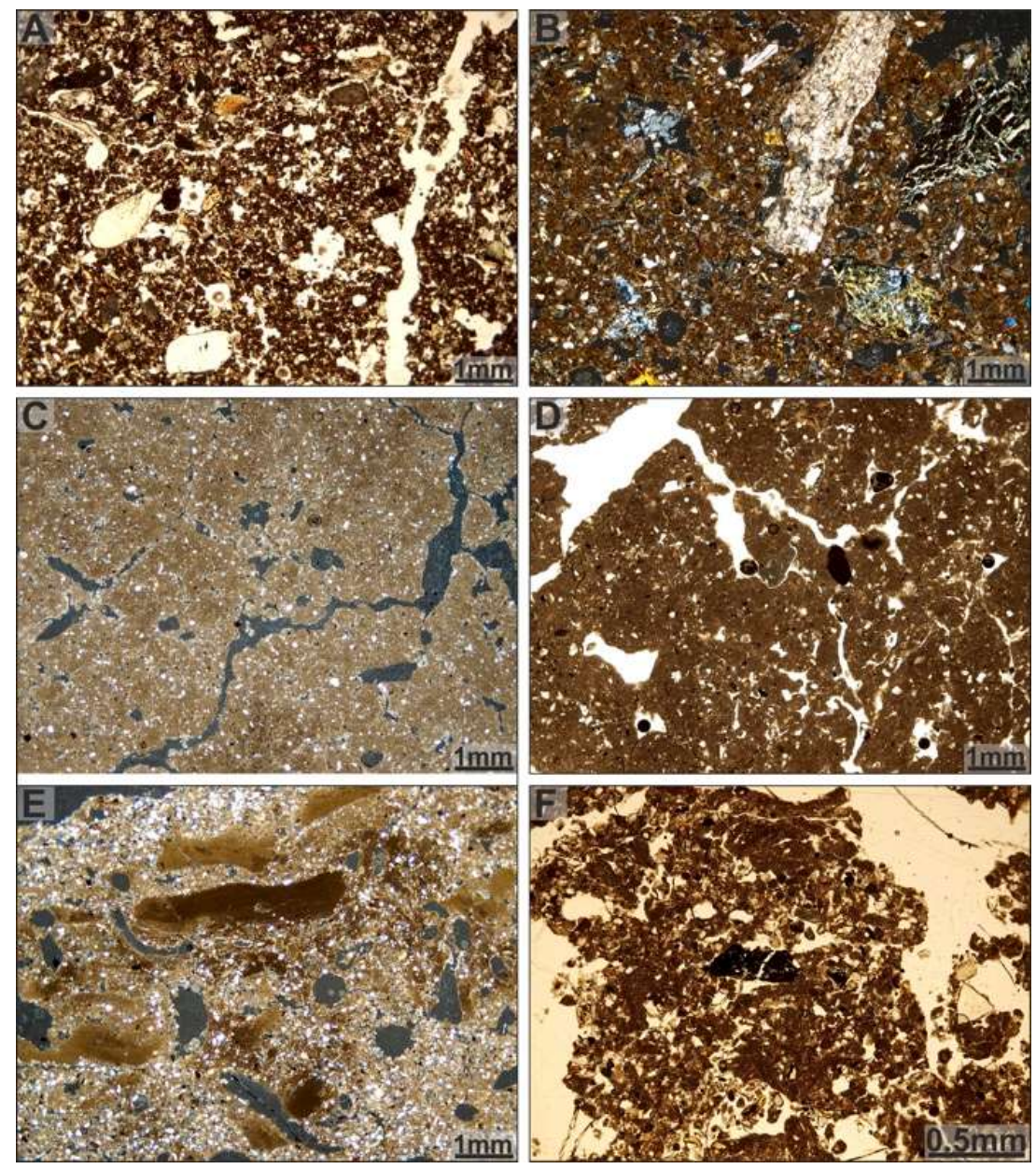

Fig. 7. Photomicrographs of soil thin sections from the study area. (A) Groundmass of the Bw soil horizon (PPL) buried below the levee's sediment of Falaj Farud. (B) Concentration of stone fragments in the Bw soil horizon (XPL) buried below the levee's sediment of Falaj Farud. (C) Angular blocky structure of the Iron Age buried soil found in the test trenches (XPL). (D) Microcharcoals interspersed in the groundmass of the Iron Age buried soil found in the test trenches (PPL). (E) Fragmented decantation crusts and common voids related to bioturbation in the Bronze Age buried soil found in the test trenches (XPL). (F) Large charcoal fragment in the Bronze Age buried soil found in the test trenches (XPL).

Open-air canals have been observed at the lower reaches of Falaj Farud, Falaj Shaww, and Falaj Bisya. They are delimited by straight levees which are between 1 to $1.8 \mathrm{~m}$ high and ca. $10 \mathrm{~m}$ wide. The open-air canals are generally ca. $1 \mathrm{~m}$ deep, because largely filled by colluvial sediments resulting after the dismantling of the levees (Fig. 6). Along Falaj Farud a trench exposed a slightly 
rubified entisol (a Bw soil horizon), buried by the levee's sediment (Fig. 5). Under the microscope, this soil horizon highlighted a blocky structure, with common voids related to bioturbation and a reddish clay-rich micromass with interspersed quartz grains and rock fragments (Fig. 7). A fragment of pottery included in the $\mathrm{Bw}$ soil horizon of the buried paleosoil has been dated to $3900 \pm 200$ years BP by thermoluminescence (Mi-D2409). When in use, these canals were most likely deeper than today. The beginning of the irrigation canal originating from Falaj Bisya is cut into the bedrock up to the depth of $5 \mathrm{~m}$, and it is filled by sediments decanted in water. The infilling of the canal includes, in the lowermost part, exclusively Iron Age pottery fragments, whereas Islamic ware is entombed at its top.

In several cases, however, a more complex relationship between aflaj and canals has been observed. The shafts of the middle part of Falaj Farud have been excavated inside the western levee of the adjoining canal, and therefore the canal predates the excavation of the falaj. Similarly, a sequence of shafts has been excavated inside a canal or, as in the case of the Falaj Farud, within the ridges of the canal, confirming the fact that these shafts follow the construction of the canal. Moreover, this evidence suggests that a substantial drop in the water table must have occurred between these two phases of falaj activity. Finally, the aflaj that were excavated inside the canals belong to the second group described above and have fresh spoil rings, which are still open and a few metres deep.

Canal Jabrin (Fig. 5), an open-air canal flowing from the north along Wadi Sayfam is worth of attention. It is $8 \mathrm{~km}$ long, ca. $3 \mathrm{~m}$ wide, and $1.5 \mathrm{~m}$ in depth. Part of Canal Jabrin is composed of earthen levees, runs on a raised section, and flows through an aqueduct across a small wadi. The aqueduct is built by stone masonry cemented by concrete, whereas the arches of the aqueducts are encrusted by a massive and highly porous calcareous tufa, indicating a hyperalkaline source for the water transported by the canal (most likely sourced from the ophiolitic rocks). A sample of this tufa was dated by radiocarbon to (UGAMS24982) 650 \pm 20 years BP (1352-1390 years cal AD). This date being consistent with fragments of glazed pottery of late sgraffiato type included inside the canal levees.

Satellite imagery show that the lower reach of Canal Jabrin branches out in a net of minor ditches in the shape of comb pins (Fig. 8), which diverge from the main canal to bring water to the surrounding areas, which are uncultivated today. The ruins of an Islamic village (Salut ruined village in Fig. 9) dating back to the $14^{\text {th }}$ century $\mathrm{AD}$ are located in close proximity to the canal (dated on the basis of the glazed Islamic pottery occurring at its surface, see Whitcomb, 1975). 


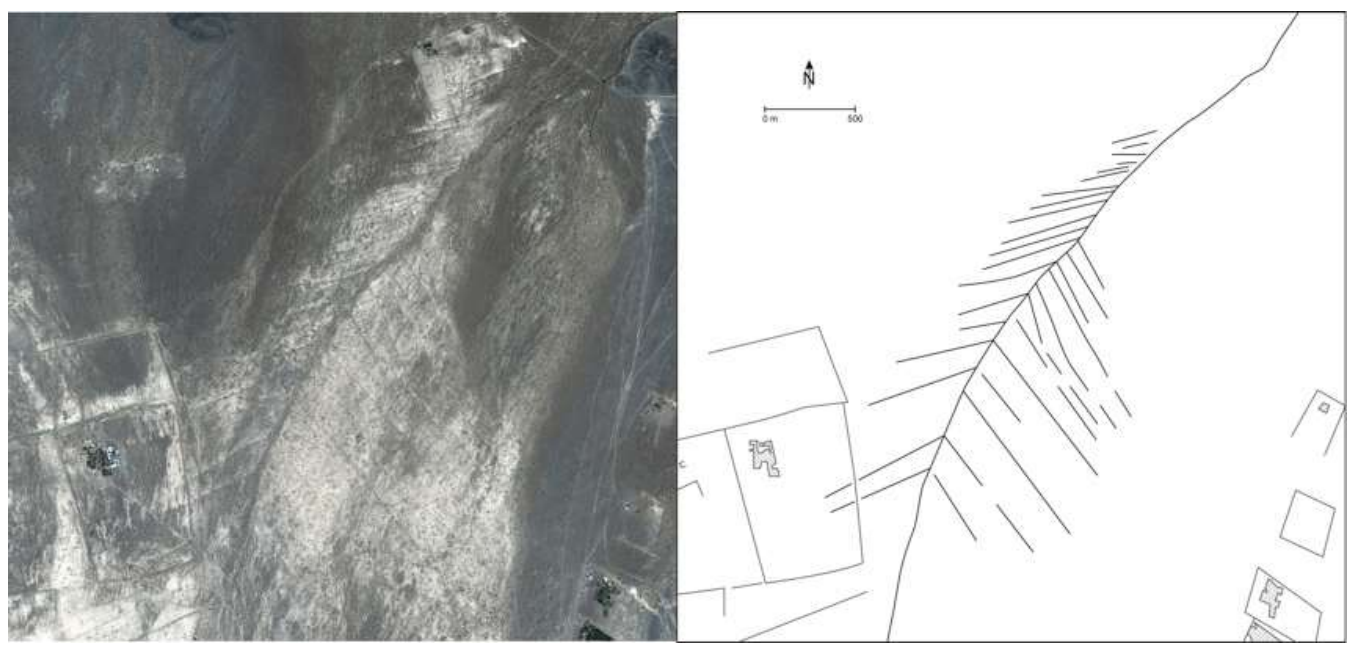

Fig. 8. The net of minor ditches in the shape of comb pins at the termination of Canal Jabrin (satellite imagery Google Earth $\left.{ }^{\mathrm{TM}}\right)$.

\subsection{The landscape of the palaeo-oasis surrounding the citadel of Salut}

Falaj Shaww, Falaj Farud, and Falaj Bisya converge in the plain surrounding the Iron Age site of Salut. The surrounding area is marked by abandoned settlements and evidence for former cultivated fields. The latter mostly consists of a network of irrigation ditches and stone or flat earthen walls, delimiting the cultivated fields to retain and prevent the fertile soil preventing from erosion and avoiding the dispersion of water. These irrigation structures and abandoned irrigated fields are evident in the field and also in high-resolution satellite imagery (Fig. 9). Surface finds of green/blue glazed Abbasid pottery, splashed ware, early and late sgraffito ware pottery dating from the $9^{\text {th }} / 10^{\text {th }}$ to the $14^{\text {th }} / 16^{\text {th }}$ centuries AD suggests that they were in use over a long period, encompassing the early and the middle Islamic periods (sensu Withcomb, 1975).

Former cultivated fields surround more than 20, small anthropogenic hills (so-called naduds; Fig. 10). Like many other Omani oases, these can be interpreted as mounds of soil, upcast during the excavation of sunken fields (Wilkinson, 2003). One of these nadud was investigated through two test trenches which revealed a series of superposed layers of dumped loose sand including organic material mixed with gravel, fragments of calcrete from the Khabra Formation, originating from the excavation of canals and/or aflaj (Fig. 10). The nadud deposits include reworked archaeological material, comprising abundant sherds from the Islamic period and fewer Iron Age pottery, the latter often occurs in scatters of many fragments or as almost complete typical vessels, including carinated cups and spouted bowls. This suggests that the formation of these mounds involved the reworking of soils and sediments from Iron Age occupation. 


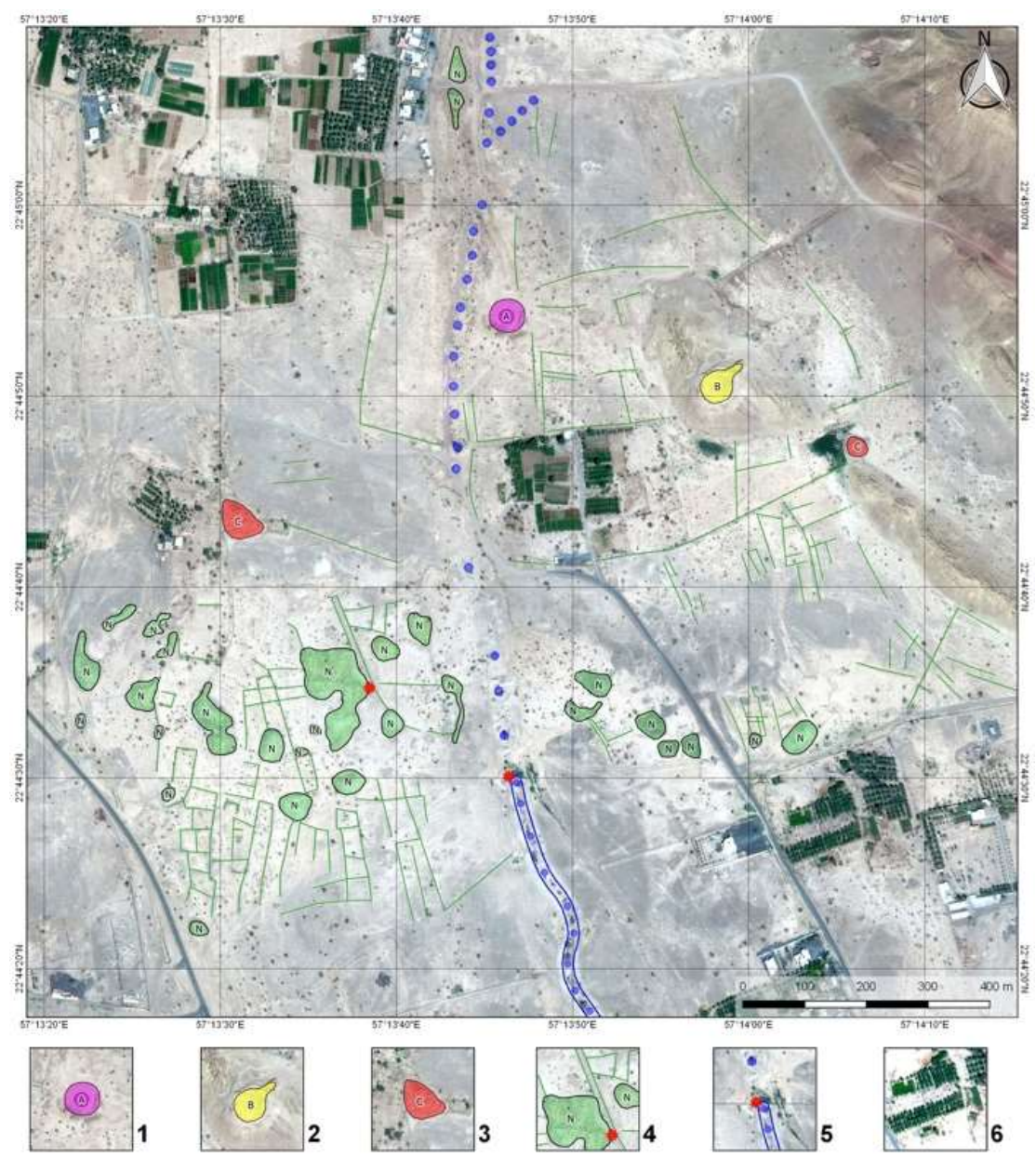

Fig. 9. Google Earth ${ }^{\mathrm{TM}}$ satellite imagery of the area surrounding the citadel of Salut suggesting water and land management. Key: 1) Bronze Age tower; 2) Iron Age citadel of Salut; 3) Late Islamic buildings; 4) nadud and stone delimitations of former fields; (the nadud indicated with the asterisk is the one described in Fig 10); 5) falaj shaft and falaj excavated in the bottom of canals; 6) present day cultivation irrigated by deep mechanically drilled wells.

Naduds protected the pristine soil of the oasis from erosion, which consists of a strongly developed Bw horizon with evidence of intense bioturbation and interspersed charcoal fragments, suggesting a sort of management of the soil of the oasis through fire (i.e. firing surfaces after harvesting). 


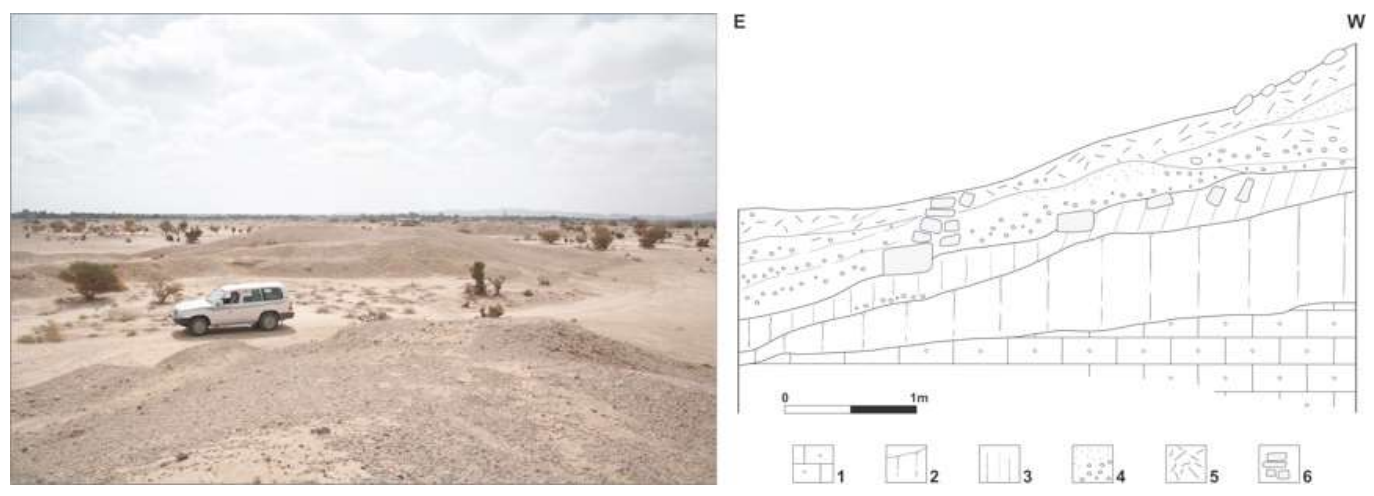

Fig. 10. On the left, view of the nadud in the area of Salut and stratigraphic sequence of one of them (on the right). Key: 1) bedrock (cemented gravel); 2) topsoil of the alluvial plain; 3) silty sand rich in vegetal remains, charcoal, and ash, including Iron Age pottery fragments; 4) loose gravel and sand; 5) loose vegetal remains (straw and coprolites); 6) stones and stone walls.

To evaluate the consistence of the soil cover in the plain surrounding the citadel of Salut, 21 test pits were excavated (Fig. 11). Test trenches indicated that the strongly cemented sediments (calcretes), are covered by 1-1.6 m of loamy sediment and a thin sandy-loamy and stony surface layer rich in pottery fragments. The loamy 1-1.6 m thick sediment sequence consists of two buried pedosedimentary levels, which are separated by a stone line. The soil horizon of the lowermost level (Fig. 4B) contains Bronze Age pottery, whereas the uppermost buried soil includes Iron Age pottery. Islamic pottery was only found in the deflated modern topsoil. Under the microscope the Iron Age soil has an angular blocky structure and presents a dense clay-rich micromass with interspersed scarce quartz grains and very few rock fragments and minute charcoal fragments (Fig. 7). On the contrary, the Bronze Age soil horizon of the lower pedosedimentary sequence is richer in quartz grains and presents many pedofeatures related to agricultural activities and soil management. This is indicated by the presence of fragmented decantation crusts, abundant voids related to bioturbation, minute to coarse charcoal fragments and few bone fragments (Fig. 7).

The surface soil (Ap horizon) of the plain of Salut is systematically dotted by pottery fragments and evidence of past human activities. The occurrence of charcoal fragments and exotic stones represents an anthropogenic input to soils and suggests a long lasting agricultural activity within the oasis (addition of fine textured sediments, manuring, irrigation, field partitioning). 


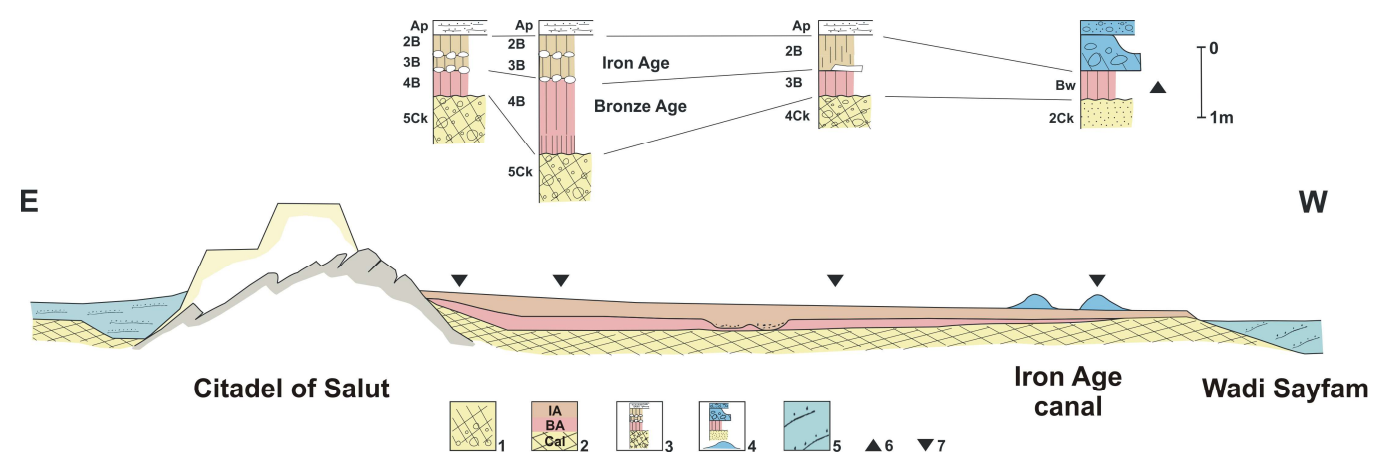

Fig. 11. Stratigraphies of some of the test trenches excavated along a cross section around the citadel of Salut (the cross section is not to scale). Key: 1) calcrete; 2) main sequences including an Iron Age pedocomplex (IA) and a Bronze Age pedocomplex (BA) (Cal is the calcrete); 3) test profiles discussed in the texts; 4) Iron Age canal and stratigraphy of its eastern levee; 5) recent wadi sediments; 6) position of the pottery fragment dated with TL; 7) position of test trenches.

\subsection{Calcareous tufa from the falaj shafts}

Along the upper $500 \mathrm{~m}$ of Falaj Shaww and Falaj Farud, several fragments of calcareous tufa were found in their shafts' spoils heaps. At one location (Falaj Shaww), these fragments were up to 30 $\mathrm{cm}$ thick and laminated and still cementing the gravel of bedrock, in which the tunnel is excavated.
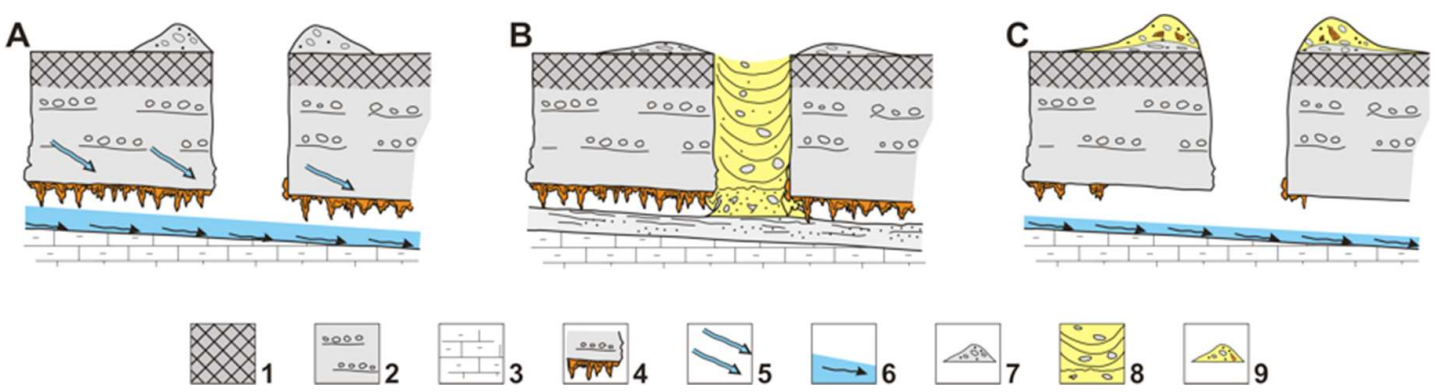

Fig. 12. Model representing the development of falaj in the region, and the formation and removal of calcareous tufa. Key: A) phase of activity; B) phase of abandonment; C) phase of late re-excavation; 1) calcrete; 2) poorly cemented gravel; 3) hard calcrete developed in marl bedrock; 4) calcareous tufa formation; 5) water table; 6) water flow inside the tunnel; 7) early sediment heaps resulting from tunnel excavation; 8) sedimentary infilling of abandoned shaft; 9) fragments of calcareous tufa within later sediment heaps resulting from tunnel cleaning.

Calcareous tufas either occur in shape of lateral flowstones, or stalactites (Fig. 12), and formed in the underground part of the falaj above the water line. They were removed during reexcavation or cleaning of the aflaj system and subsequently thrown to the surface. Some of the largest concretions display a squared shape in their upper part, as they were moulded on a large 
and regularly shaped surface. This evidence proves that they come from a falaj artificial tunnel, and is supported by recent findings along the Wadi Bahla, where gravel extraction from the wadi exposed squared tunnel sections (Phillips et al., 2010).
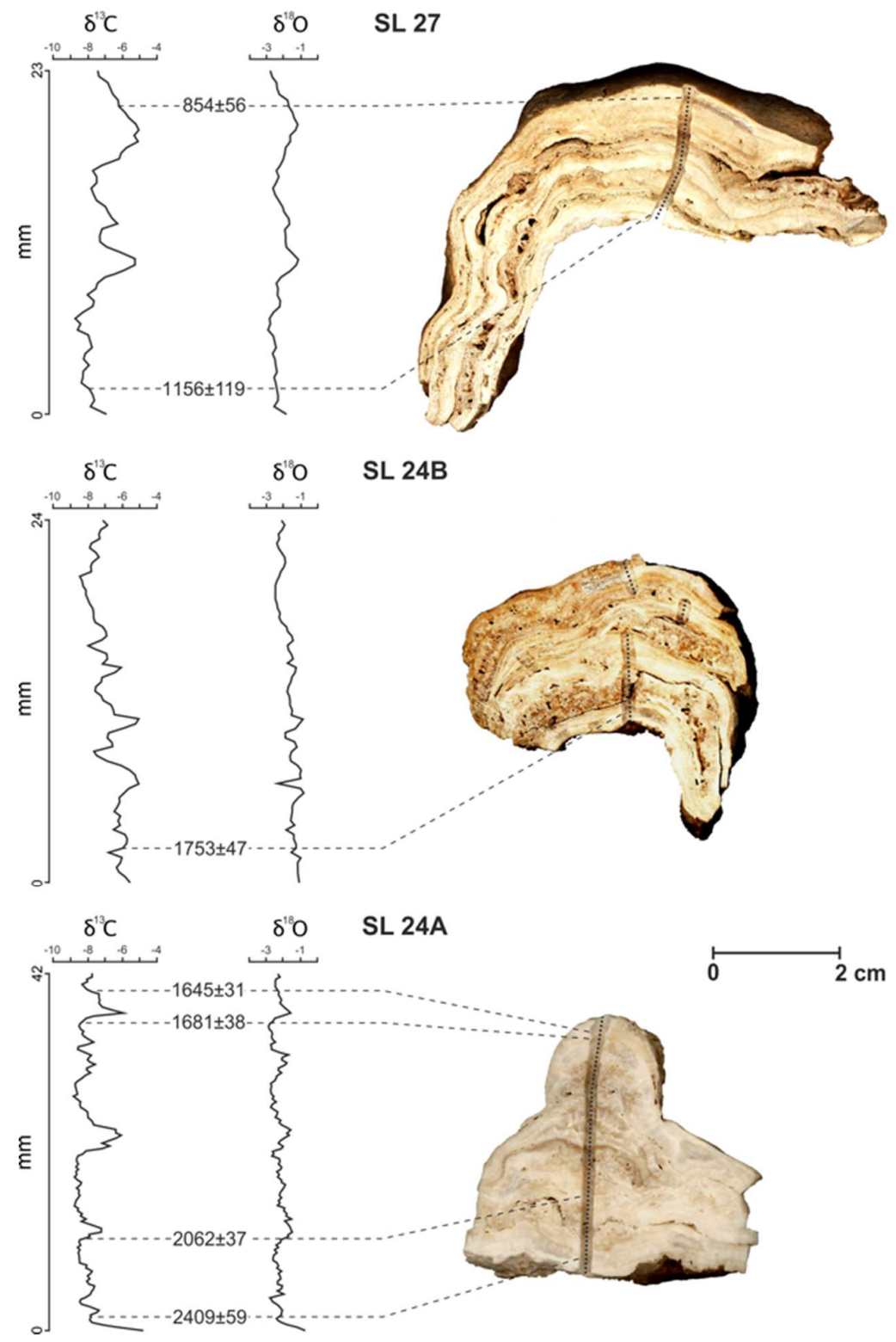

Fig. 13. Stable isotopic composition of carbon and oxygen of each sample; all ages are given as years BP. Dated specimens of calcareous tufa showing the location of dated samples and results.

Three different specimens of calcareous tufa have been collected for U/Th dating and stable isotope analysis: samples SL 24A, SL 24B, and SL 27 (Fig. 13). They were selected on the basis of their macroscopic appearance and absence of detrital layers. Sampled flowstone-type tufa (Pentecost, 2005) are laminated (ondulated laminae), white to light gray in color and well lithified. 
The very compact and dense laminated structures are occasionally interrupted by thin porous laminae (possibly stromatolithic). The thickness of the laminae varies greatly from $0.2-0.5 \mathrm{~mm}$ to 1 $2 \mathrm{~mm}$. Optical microscope and SEM investigations on a few samples confirm the differences in the fabric observed under the optical microscope; compact strata consists of giant rays/bladed calcite macrocrystals which are separated by thin micritic layers. In contrast, the most porous laminae frequently consist of micritic to microsparitic crystals (Fig. 14).
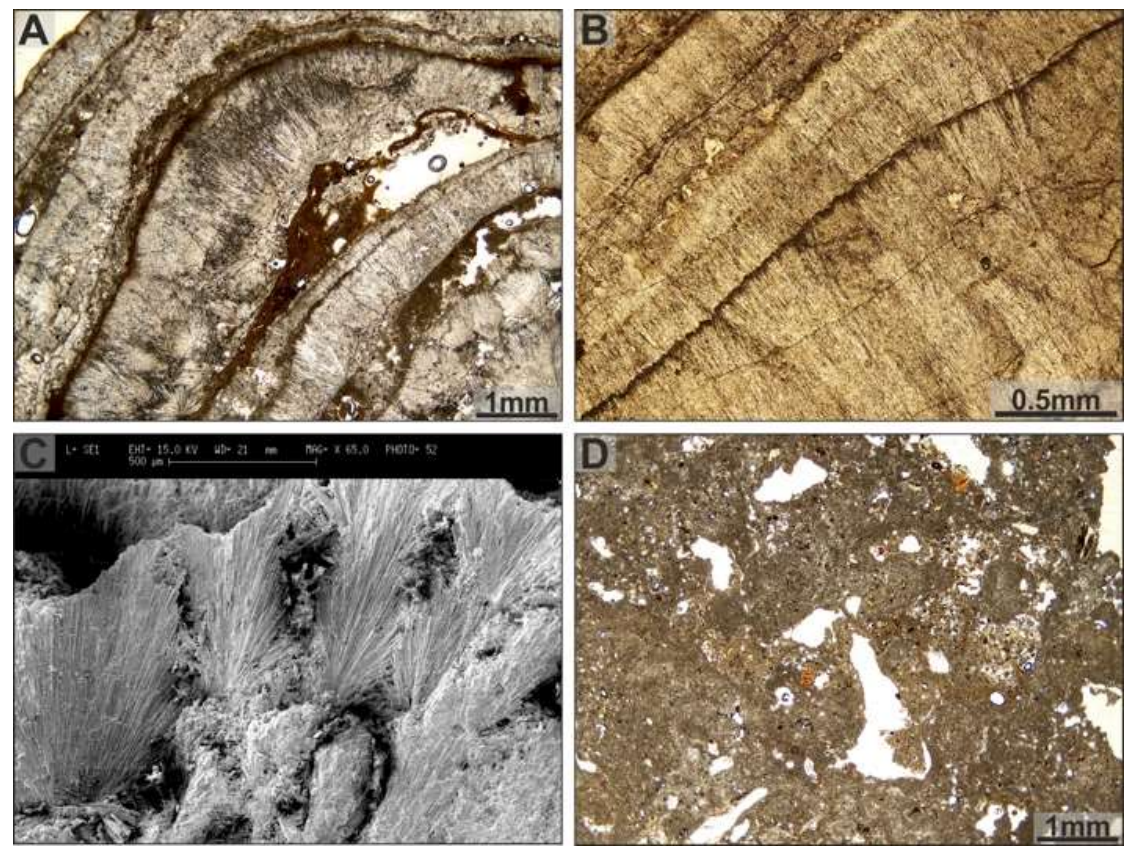

Fig. 14. Photomicrographs of the calcareous tufa. (A) Thick laminae in sample SL27 (PPL). (B) Detail of the giant rays macrocrystals in sample SL24 (PPL). (C) SEM image of the giant rays macrocrystals in sample SL24. (D) Spongy structure of the calcareous tufa from Canal Jabrin.

Seven samples obtained from these three concretions were U/Th dated (Tab. 1). Four dates were obtained from sample SL 24A. One of the sub-samples for dating was taken from the base of the specimen, two from its top, and one in the central part of the tufa, in correspondence to a lithological discontinuity. Sub-samples were collected at the base of specimen SL 24B, and at the base and top from specimen SL 27. Calcareous tufa from Falaj Shaww displays very high U concentrations of around $9 \mathrm{ppm}$ and U-series dates are in stratigraphic order for samples SL 24A and SL 27 (Tab. 1, Fig. 13) despite a low to moderate content of detrital thorium (indicated by lower ${ }^{230} \mathrm{Th} / 232 \mathrm{Th}$ activity ratios) and correction for detrital contamination. U-series dates suggest that the formation of calcareous tufa covered a long time span ranging from ca. 400 BCE to ca. 1150 
CE. Calculated growth rates for samples SL 24A and SL 27 are generally low and range from 0.06 to $0.08 \mathrm{~mm} \mathrm{yr}^{-1}$ for sample SL 24A and SL 27 respectively. Such low growth rates are in good agreement with typical growth rates freshwater carbonates (Capezzuoli et al., 2014). In the case of sample SL 24A, where $4 \mathrm{U} / \mathrm{Th}$ dates are available, the growth rate did not change significantly before and after a main lithological discontinuity above sub-sample 6-SL24A (0. 057 and 0.055 $\mathrm{mm} / \mathrm{y})$.

\begin{tabular}{|c|c|c|c|c|c|c|c|c|c|c|c|c|}
\hline Sample & $\begin{array}{l}\text { Sample thicness } \\
\text { (mm) }\end{array}$ & $\begin{array}{l}\text { Distance from the base } \\
(\mathrm{mm})\end{array}$ & $\begin{array}{l}\mathrm{U} \\
\mathrm{ppb}\end{array}$ & $\begin{array}{l}\text { Th } \\
\mathrm{ppb}\end{array}$ & 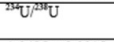 & ${ }^{200} \mathrm{Th} / 25 \mathrm{Th}$ & ${ }^{20} \mathrm{Th}^{2 / 2} \mathrm{U}$ & Tnitial $234 \mathrm{TT} / 238 \mathrm{TT}$ & $\begin{array}{l}\text { U/Th age } \\
(\mathrm{yr} B P) \pm 2 \sigma\end{array}$ & $\begin{array}{l}\text { Error } \\
\%\end{array}$ & $\begin{array}{l}\text { Age detr. corr. } \\
\text { (y BP) } \pm 2 \sigma\end{array}$ & $\begin{array}{l}\text { Age } \\
\text { (yr BCE/CE) }\end{array}$ \\
\hline 3-SL24A & 42 & 3 & $9814.9 \pm 15.8$ & $4.8 \pm 0.1$ & $1.0425 \pm 0.0015$ & $142.5426 \pm 3.4458$ & $0.0219 \pm 0.0003$ & $1.043 \pm 0.003$ & $2424 \pm 62$ & 2.6 & $2409 \pm 59$ & $401 \mathrm{BCE}$ \\
\hline 6-SL24A & & 11 & $9511.2 \pm 16.6$ & $3.6 \pm 0.0$ & $1.0334 \pm 0.0019$ & $153.4658 \pm 1.6386$ & $0.0188 \pm 0.0002$ & $1.034 \pm 0.004$ & $2074 \pm 35$ & 1.8 & $2062 \pm 37$ & $54 \mathrm{BCE}$ \\
\hline 5-SL24A & & 36 & $10620 \pm 14.8$ & $2.1 \pm 0.0$ & $0.9915 \pm 0.0012$ & $227.6695 \pm 5.7579$ & $0.0153 \pm 0.0002$ & $0.992 \pm 0.002$ & $1686 \pm 40$ & 2.4 & $1681 \pm 38$ & $327 \mathrm{CE}$ \\
\hline 4-SL $24 \mathrm{~A}$ & & 39 & $14262.7 \pm 20.4$ & $3.3 \pm 0.0$ & $0.9983 \pm 0.0008$ & $197.0977 \pm 2.1449$ & $0.0150 \pm 0.0001$ & $0.998 \pm 0.002$ & $1650 \pm 32$ & 1.9 & $1645 \pm 31$ & $363 \mathrm{CE}$ \\
\hline 1-SL24B & 24 & 3 & $15087.7 \pm 22.6$ & $35.4 \pm 0.1$ & $1.0123 \pm 0.0013$ & $21.4895 \pm 0.1953$ & $0.0165 \pm 0.0001$ & $1.012 \pm 0.003$ & $1820 \pm 34$ & 1.9 & $1753 \pm 47$ & $255 \mathrm{CE}$ \\
\hline $\begin{array}{l}\text { 7-SL } 27 \\
\text { 8-SL } 27\end{array}$ & 23 & $\begin{array}{l}2 \\
21\end{array}$ & $\begin{array}{l}8183.7 \pm 11.5 \\
9166.8 \pm 12.9\end{array}$ & $\begin{array}{l}63.1 \pm 0.3 \\
26.3 \pm 0.1\end{array}$ & $\begin{array}{l}1.0841=0.0009 \\
1.0996 \pm 0.0009\end{array}$ & $\begin{array}{l}5.3069 \pm 0.0815 \\
9.8568 \pm 0.1837\end{array}$ & $\begin{array}{l}0.0125 \pm 0.0002 \\
0.0085 \pm 0.0002\end{array}$ & $\begin{array}{l}1.084 \pm 0.002 \\
1.100 \pm 0.002\end{array}$ & $\begin{array}{l}1373 \pm 41 \\
936 \pm 37\end{array}$ & $\begin{array}{l}3.0 \\
4.0\end{array}$ & $\begin{array}{l}1156 \pm 119 \\
854 \pm 56\end{array}$ & $\begin{array}{l}852 \mathrm{CE} \\
1154 \mathrm{CE}\end{array}$ \\
\hline
\end{tabular}

Tab. 1. U/Th dating results for the calcareous tufa from the Salut plain (ratios are activity ratios expressed with $2 \sigma$ uncertainties).

The $\delta^{18} \mathrm{O}$ and $\delta^{13} \mathrm{C}$ values of tufa were measured as proxies for changes in rainfall and soil/vegetation composition (Pentecost, 2005). $\delta^{18} \mathrm{O}$ values of tufa samples vary between -2.94 and $0.71 \%$ around an average of $-2.05 \%$, whereas $\delta^{13} \mathrm{C}$ values range from -8.85 to $-4.80 \%$, with an average of $-7.48 \%$. In general, $\delta^{18} \mathrm{O}$ and $\delta^{13} \mathrm{C}$ values in terrestrial carbonates are often influenced by isotopic fractionation occurring during degassing of $\mathrm{CO}_{2}$ and evaporation during the precipitation of calcite (Hendy, 1971; Fairchild et al., 2006). Tufa-precipitating systems are only likely to approximate isotopic equilibrium (Andrews et al., 2000), and isotopic data can be used for palaeoclimatic reconstruction when evaporation effects are taken into account (Frisia et al., 2002; Horvatincic et al., 2003; Smith et al., 2004; Pentecost, 2005; Cremaschi et al., 2010, 2015). The Hendy Test (Hendy, 1971) describes the rate of kinetic fractionation occurred in continental carbonates (mainly speleothems), and in the case of concretions from Falaj Shaww the correlation between $\delta^{18} \mathrm{O}$ and $\delta^{13} \mathrm{C}$ values is moderate to high (Fig. 15), with the highest $\mathrm{r}^{2}$ value in sample SL 27 $\left(\mathrm{r}^{2}=0.89\right)$. Considering the influence of isotope fractionation and high evaporation in this area, the correlation plots of Fig. 13 may indicate that in samples SL 24A and SL 24B calcite precipitated close to isotopic equilibrium, whereas the high correlation coefficient of sample SL 27 suggests a higher kinetic influence on fractionation during deposition. The comparison between tufa and the Hoti Cave stalagmite record suggests that in our samples evaporational effects were fairly low. Moreover, measured values are comparable with those fed by rainfall and reported by Stephen et al. (2013) for the typical soil zone travertine (soil carbonate) found in the Sultanate of Oman. 

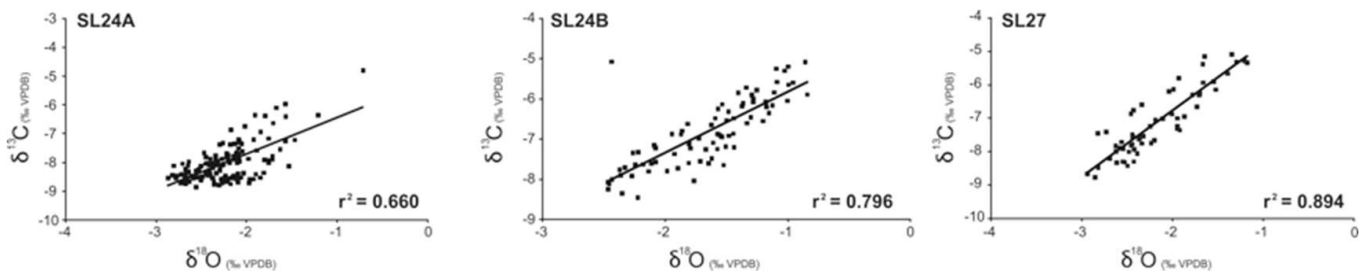

Fig. 15. Hendy test. The cross plots of $\delta^{18} \mathrm{O}$ versus $\delta^{13} \mathrm{C}$ for each sample.

The radiocarbon date of the highly porous tufa developed on the masonry of the aqueduct of Canal Jabrin was 650 \pm 20 uncalibrated years BP (UGAMS24982), 1284-1390 cal years AD. We also measured stable isotopes on this sample: values ranged between -1.43 and $-6.63 \%$ ond -1.32 and $4.86 \%$ for $\delta^{13} \mathrm{C}$ and $\delta^{18} \mathrm{O}$ respectively. Also in this case, the isotopic signature is compatible with soil zone travertine and suggests an affinity with a $\mathrm{C} 4$ type soil $\mathrm{CO}_{2}$ (Clark and Fontes, 1990).

\section{Discussion}

\subsection{The beginning of intensive agriculture in the palaeo-oasis of Salut}

The accumulation of thick deposits of wind-blown dust (Khabra Formation) in the Wadi Sayfam area during the wet Early Holocene determined the later suitability of the area for human settlements and farming, which becomes a relevant activity during the Bronze Age, as attested by the important concentration of monuments (towers and cairns) dated to that period.

The citadel of Salut and the large village surrounding it (Avanzini and Phillips, 2010; Avanzini and Degli Esposti, 2018) represented the centre of a larger settlement network that was established during the Iron Age (Condoluci et al., 2014). The widespread presence of Iron Age pottery in the soils of the plain and in the nadud suggests the existence of a large cultivated oasis during this period. It is therefore very likely that the original surface irrigation systems were contemporary to this use; in fact, the irrigation facilities appear pivotal to the development of the oasis in this phase. Moreover, on the basis of associated pottery, irrigation facilities sustained agriculture for a long period, including the early Islamic era $\left(9^{\text {th }}-10^{\text {th }}\right.$ to $14^{\text {th }}-15^{\text {th }}$ centuries $\left.A D\right)$.

\subsection{Dating the introduction and implementation of the falaj system}

Absolute and relative dating of the archaeological finds structures allows determining the timing of the introduction of irrigation system in the region. An age post quem for the excavation of Falaj Farud's open-air canal is represented by the TL age of $3900 \pm 200$ years BP obtained from a potsherd 
found in the buried Bw horizon in the Khabra Formation. In the region, this period corresponds to the transition between the Early and Middle Bronze Age (e.g. Magee, 2014). Moreover, a more robust chronology ante quem for the construction of the aflaj system is provided by the U/Th dating of the calcareous tufa accreted in the underground parts of Falaj Shaww. The age of tufa suggests a long period of use from ca. 400 BCE to 1150 CE.

More in detail, the earliest date related to the deposition of tufa $(2409 \pm 59$ years BP, $401 \mathrm{BCE})$ indicates that the cavity already existed before this period, and thus the construction of the falaj is most likely connected at least to the final centuries of the Iron Age. Recent archaeological data confirm this observation as they suggest that the site continued to be inhabited during the late Iron Age, much more consistently than previously believed (Avanzini and Degli Esposti, 2018). If we consider this information together with results of a wider archaeological survey (Condoluci et al., 2014), and recently published archaeological survey data we may suggest that at the end of the Iron Age the area of Wadi Sayfam was still densely inhabited and exploited for cultivation. Moreover, the date falls into the Iron Age III period (Magee, 1996), or Late Iron Age (sensu Phillips et al., 2010), when there is strong evidence for Achaemenid influence and possibly also direct control over southeast Arabia (Potts, 1985, 1990).

Such a date helps to answer the question whether the aflaj technique was introduced in Oman under the Achaemenid influence or the outcome of local developments. When combined with the archaeological discoveries of the last twenty years (e.g. al Tikriti, 2002, 2010), data from tufa collected from another falaj near Nizwa, not far from Salut (Fig. 1), reveal that this falaj conveyed water to its final, open channel section between the $10^{\text {th }}$ and the $9^{\text {th }}$ century BCE (Clark and Fontes, 1990). These dates in good agreement with the local Iron Age chronology and predate the Achaemenid influence by approximately 400 years. The presence of such an ancient falaj also fits the available archaeological data for the Nizwa oasis, were dense Iron Age occupation is reported (Schreiber, 2007).

The other available dates obtained for tufa formation raise the question of the occupation of the area during the Parthian and especially Sasanian periods. In fact, after the conquest by Ardashir in the first half of the $3^{\text {rd }}$ century AD (e.g. Fiorani Piacentini, 1985), Sasanians remained in the country for centuries, signing a treaty with the local Julanda family belonging to the Azd tribe during the $6^{\text {th }}$ century AD, according to which Sasanians would have controlled the coast, while the Azd would have ruled the mountains and the interior (Wilkinson 1975; Al-Naboodah 1992; Kennet 2007; Yule 2008). However, it is only local tradition that attributes to the Persians (i.e., 
Sasanians), the original foundation of the Bahla fort. Be that as it may, the aflaj system was active during the Early and Middle Islamic periods, as confirmed by the presence of blue glazed pottery and late sgraffiato ware within the oasis' limits. The most recent age for tufa formation (854 \pm 56 years $\mathrm{BP}, 1154 \mathrm{AD})$ indicates that after this period the condition suitable for tufas deposition ceased, most likely as a consequence of a drop of the water table in the valley of wadi Sayfam. As a result it was necessary to dig new shafts in the open channels and/or to deepen the previous ones to follow the dropping of the water table after the $12^{\text {th }}$ century AD. Written evidence may however offer an alternative explanation. Specifically, the study of a $13^{\text {th }}$ century AD collection of judgements by Wilkinson $(1977 ; 1983)$ highlighted how the area of Salut was the object of one of the most significant cases dealing with rights on abandoned lands. In fact, some time before the end of the $11^{\text {th }}$ century $\mathrm{AD}$, the area was illegally seized and was rapidly abandoned as eating, selling, or buying anything coming from this area was prohibited. Ceased maintenance of the aflaj tunnels might have led to their obliteration and thereby interrupting tufa formation. The first initiative aimed at regularizing this situation, allowing cultivation, is recorded in the $15^{\text {th }}$ century, and was followed by opposing decisions until the ban was finally lifted. In addition, the Hoti Cave $\delta^{18} \mathrm{O}$ record indicates increased rainfall during this phase (Fleitmann et al., 2007), suggesting that climate may have favoured the decision to reactivate the local irrigation system.

This latter piece of information is broadly consistent with other archaeological data. For instance, the occurrence of late sgraffiato ware in relation with the cultivated areas may indicate a later re-activation of the irrigation system in the middle Islamic period. Besides, the most recent radiometric dating of calcareous tufa is the AMS $-{ }^{14} \mathrm{C}$ age of the porous tufa found along the brickwork part of Canal Jabrin; this tufa formed around 1284-1390 cal years AD (Middle Islamic period), thus 150-250 years after the deactivation of Falaj Shaww. The construction of Canal Jabrin is possibly the consequence of a reduction in precipitation, driving the exhaustion of the aquifer feeding the aflaj along Wadi Sayfam. This dry episode occurred at around 1150 AD (termination of tufa accretion within the falaj). In the Middle Islamic period thus, water shortage may have been the reason why the inhabitants of the Salut oasis abandoned the aflaj system and collected water from springs located along the foothills, although different, socio-political reasons cannot be ruled out (mentioned above).

Only in a later phase, not yet identified, the aflaj were reactivated by excavating deeper shafts to catch the water table and they continued to bring water to farms up to a few decades ago. 


\subsection{Palaeoclimatic significance of calcareous tufa and comparison with regional palaeohydrological proxies}

If we consider the isotopic transects for the calcareous tufa of Falaj Shaww (Fig. 13) we note a substantial stability of $\delta^{18} \mathrm{O}$, with few less negative peaks, which may be related to short-time decrease in precipitation one of these phases is documented in sample SL 24A and dated to 2000 years BP. The general trend of each curve suggests that during the first phase of tufa formation the availability of meteoric water was greater than in the later phase of tufa growth. Moreover, the measured $\delta^{18} \mathrm{O}$ of our samples are very similar to those measured by Burns and Matter (1995) in several carbonate cements and to Fleitmann et al. (2007) in the late Holocene stalagmites from the Hoti Cave. On the contrary, the $\delta^{13} \mathrm{C}$ curves are more articulated and marked by several less negative peaks; as the variability in soil metabolism and vegetation structure at low latitude is a direct effect of changes in precipitation (Andrews, 2006), the peaks observed in Fig. 13 are possibly related to the shift from C3-dominated to mixed C3 and C4 vegetation as consequence of reduced water availability in the catchment area. The surface aquifer recharging Falaj Shaww and promoting tufa deposition was disconnected from the areas devoted to intensive cultivation, and therefore the carbon isotope signal should only be marginally affected by any human contribution related to changes in the local land use.

If one takes into account the time and steps of agricultural activities in the study region and the evolution of irrigation facilities from the Bronze Age onward and compares it with the regional palaeohydrological record, it may be possible to infer whether climatic reasons triggered the introduction of the falaj system in this part of the Sultanate of Oman. The most reliable climatic proxy for the area is the $\delta^{18} \mathrm{O}$ curve elaborated on speleothems from the Hoti Cave (Fleitmann et al., 2007), which is located only a few kilometres from the Salut area and thus belongs to the same climatic domain. In Fig. 16, data from Hoti Cave are plotted together with those collected during the study in the oasis of Salut concerning the introduction of intensive agriculture and the building of irrigation facilities. 


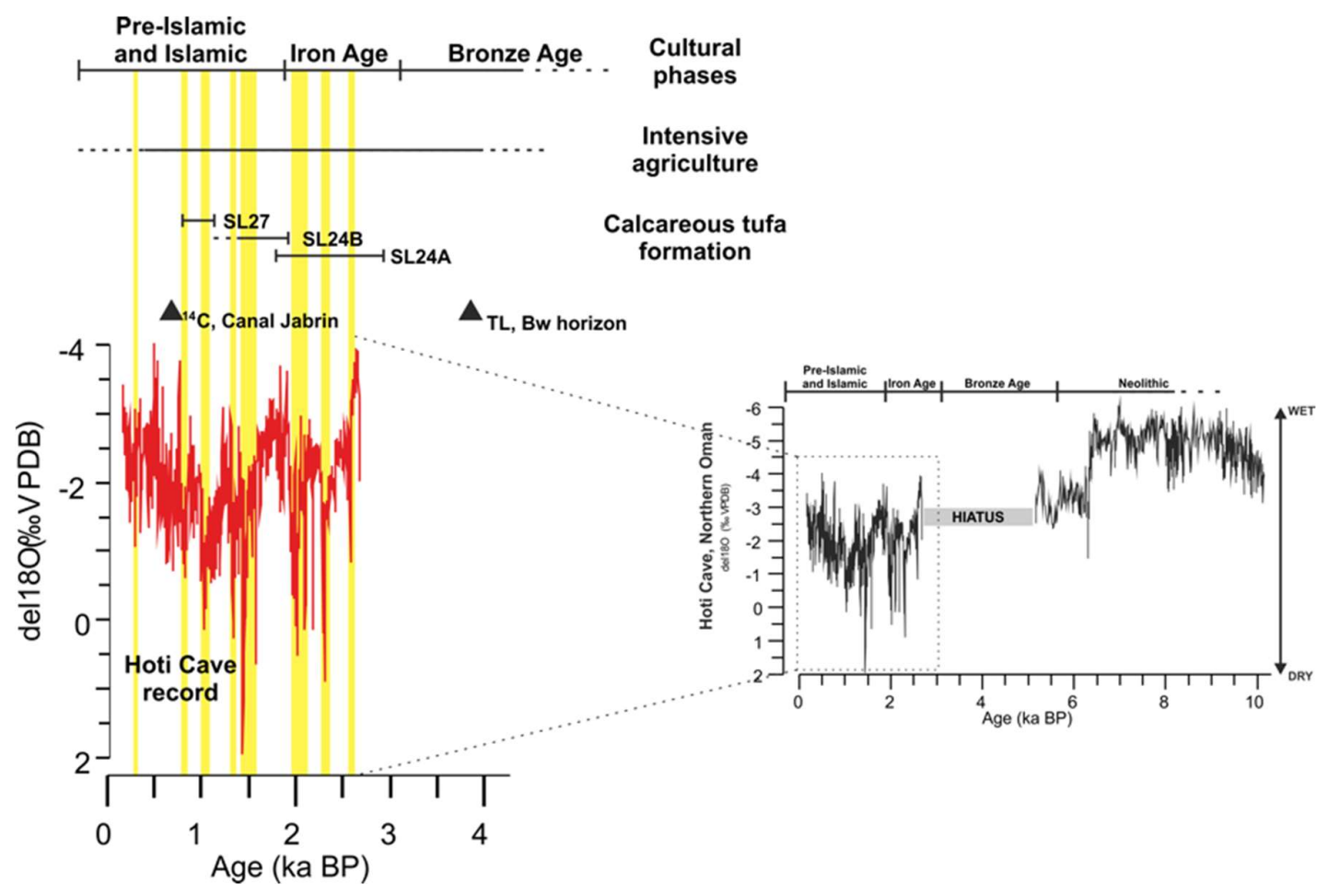

Fig. 16. Comparison between data collected in this study with the palaeohydrological archive of the speleothems from the Hoti Cave (Fleitmann et al., 2007). Available dating for the irrigation facilities and cultural phases are indicated. Vertical yellow bars indicate possible arid spells.

Human occupation of the palaeo-oasis of Salut started presumably in the Early Holocene, when water availability was considerable higher than today and allowed the Neolithic exploitation of the area and the accumulation of the Khabra Formation, which later would have represented the substrate sustaining the cultivations. In the Hoti Cave record, this phase is clearly marked by intense monsoonal rainfall, slightly decreasing towards the Mid-Holocene transition (Fleitmann et al., 2007). The phase of decreasing precipitations is followed in this record by a two-millennia long hiatus, which covers also the Bronze Age, the phase, which saw the establishment of the first systematic agricultural exploitation of the Salut oasis. If we consider an analogous, but more continuous, palaeohydrological record from southern Oman (Qunf and Defore Cave: Fleitmann et al., 2007), we notice that this phase is still marked by a decrease in the intensity of precipitations, thus indicating a progressive weakening of the monsoon system. The decrease in water availability may have hit also Northern Oman, thus pushing local communities, which were intensively cultivating the area as confirmed by microscopic evidence in buried soils, to introduce some system for water procurement and management (but not yet the falaj technology). The introduction of some kind of irrigation facilities in the Bronze Age is confirmed by field evidence 
in the area of Salut and recently described also in the Ma'rib oasis of Yemen (Kühn et al., 2010). Also at Bat in central Oman, not far from Salut, evidence for irrigation practices mainly involving an early control of the wadi floods has been dated to the $3^{\text {rd }}$ millennium BCE (Desruelles et al., 2016).

The radiometric post quem (TL dating of the Bw horizon covered by the sediments of the shaft of a falaj) and ante quem (U/Th dating of tufa) data related to the establishing of the falaj system in the area of Salut suggest that the underground system was established in the Iron Age, possibly around the mid-1 $1^{\text {st }}$ millennium BCE and then active at least up to the end of calcareous tufa sedimentation, which is dated to the Early Islamic phase ( $1^{\text {st }}$ millennium CE). The speleothem from Hoti Cave suggests that the introduction and the first phase of use of the falaj coincided with several positive $\delta^{18} \mathrm{O}$ peaks, indicating substantial arid conditions and suggesting the necessity to collect more water from distant aquifers to sustain the oasis. As suggested above, the interruption of calcareous tufa formation should be related to the (temporary) abandonment of the falaj system and resultant filling of the tunnels with sediments. It is interesting to highlight that the beginning of this phase and the building of the Canal Jabrin correspond with a moderate increase in precipitation in the $\delta^{18} \mathrm{O}$ record from Hoti Cave. This association suggests that the moderate increase in surface water availability in the area allowed using irrigation facilities that were less complex and time-consuming in terms of maintenance than the falaj system. In contrast, it is likely that the abandonment of the falaj system during the pre-Islamic or Early Islamic periods were not related to climate but rather to demographic changes or settlement shifts as a result of sociocultural transformations, such as the mentioned ban on land exploitation. Finally, we have no clear data on the subsequent reactivation of the falaj system in Northern Oman, but it occurred during the Middle Islamic period, which was, from a palaeoclimatic point of view, favoured perhaps by a period of slightly enhanced precipitation as recorded in the Hoti Cave record.

\section{Conclusions}

During the Middle Bronze Age, the intensive human occupation of the palaeo-oasis along wadi Sayfam (around the citadel of Salut) was supported by a thick soil, which was formed during a

period of considerably higher rainfall. Evidence of agricultural practice is provided by micromorphological observations, which indicate soil management practice including topsoil reworking, post cultivation firing, and manuring. U/Th and $\mathrm{AMS}-{ }^{14} \mathrm{C}$ dating on calcareous tufa that encrusted the underground tunnels of the falaj indicate that the underground system were 
already active at around 540 years BCE and able to sustain irrigation in the oasis during the Iron Age, in the later Achemenid period, and in Early and Middle Islamic phases. Surface archaeological finds may be referred mainly to the Islamic era, while archaeological evidence of previous phases is represented by allochthonous pottery fragments in the nadud mounds. Water availability inside the aflaj system ceased at around 1150 years CE, when it was exhausted by a drop in the water level, possibly related to changes in amount of regional precipitation. Consequently during the $14^{\text {th }}$ century $C E$, water for irrigation was derived through a canal from the area of Bahla, where water availability still subsisted.

The establishment of the Mid-Late Holocene agricultural exploitation of the oasis of Salut in Northern Oman and the reconstruction of the introduction and evolution of irrigation facilities represents an interesting case of anthropogenic modification of the landscape (Zanchetta et al., 2013). As common, the survival of human communities in marginal (arid to semi-arid) environments requires (i) a resilient adaptation to environmental conditions (Zerboni et al., 2016), or (ii) an active effort to identify the best technological solution to maximize the yield of limited natural resources (in this case water availability and soil suitable for cultivation). At Salut and along the nearby wadis, human communities adopted many strategies to sustain intensive agriculture; the latter was supported by the occurrence of a fertile soil formed in the Early Holocene. The high agricultural productivity required for sustaining large communities was secured by the continuous evolution of water management systems from the Bronze Age to the Islamic period, mostly in response to changes in water availability. The present case study confirms that in arid lands communities were able to actively modulate their response to climate changes with a variety of technological strategies.

\section{Acknowledgments}

We would like to express our gratitude to A. Avanzini, Director of the Italian Mission to Oman (MITO), and to the Omani authorities, whose help made the geoarchaeological research in the region possible. Many thanks to C.S. Phillips for providing archaeological and epigraphic information. A. Rizzi (IDPA-CNR) is thanked for helping with the SEM-EDS. D. Williams is gratefully acknowledged for revising the English text.

\section{References}


Aitken, M.J., 1985. Thermoluminescence dating. Academic Press, London.

Al-Jahwari, N., 2009. The agricultural basis of Umm an-Nar society in the northern Oman peninsula (2500-2000 BC). Arabian Archaeology and Epigraphy 20/2, 122-133.

Al-Marshudi, A.S, 2007. The falaj irrigation system and water allocation markets in northern Oman. Agricultural Water Management 91, 71-77.Al-Naboodah, H.M., 1992. The commercial activity of Bahrain and Oman in the early Middle times. Proceedings of the Seminar for Arabian Studies 22, 81-96.

Alsharhan, A.S., Rizk, Z.A., Nirn, A.E.M., Bakhit, D.W., Alhajari, S.A., 2001. Hydrogeology of an arid region: the Arabian Gulf and adjoining areas. Elsevier, Amsterdam.Al Sulaimani, Z., Helmi, T., Nash, H., 2007. The Social Importance and Continuity of falj Use in Northern Oman. In: Proceedings of the International History Seminar on Irrigation and Drainage. 2 - 5 May 2007,Tehran, Iran.

Al Tikriti, W.Y., 2002. The south-east Arabian origin of the falaj system. Proceedings of the Seminar for Arabian Studies 32, 117-138.

Al Tikriti, W.Y., 2010. Heading north. An ancient caravan route and the impact of the falaj system on the Iron Age culture. In: Avanzini, A., (Ed.), Eastern Arabia in the first milllennium BC, International Conference, Pisa $12^{\text {th }}-13^{\text {th }}$ May 2008, Arabia Antica 6, $1^{\prime}$ «Erma» di Bretschneider, Roma, Italy, 227-247.

Anderson, D.G., Maash K.A., Sandweiss D.H., 2007. Climate change and cultural dynamics. A global perspective on mid-Holocene transitions. Academic Press, London.

Andrews, J.E., 2006. Palaeoclimatic records from stable isotopes in riverine tufas: synthesis and review. Earth-Science Reviews 75, 85-104.

Andrews, J.E., Pedley, M., Dennis, P.F., 2000. Palaeoenvironmental records in Holocene Spanish tufas: a stable isotope approach in search of reliable climate archives. Sedimentology 47, 961978.

Avanzini, A., (Ed.), 2015. In the heart of Oman. The castle of Salut. (Ancient Oman, 1). L'«Erma» di Bretschneider, Roma, Italy.

Avanzini, A., Degli Esposti, M., 2018. Husn Salut and the Iron Age of South East Arabia. Excavations of the Italian Mission To Oman 2004-2014, Arabia Antica 15, l'«Erma» di Bretschneider, Roma, Italy. 
Avanzini, A., Phillips, C., 2010. An outline of recent discoveries at Salut in the Sultanate of Oman. In: Avanzini, A., (Ed.), Eastern Arabia in the first milllennium BC, International Conference, Pisa $12^{\text {th }}-13^{\text {th }}$ May 2008, Arabia Antica 6, 1'«Erma» di Bretschneider, Roma, Italy, 93-108.

Avanzini, A., Sedov, A., Condoluci, C., 2005. Salut, Sultanate of Oman Report (2004-2005). Egitto e Vicino Oriente 28, 339-389.

Bailiff, I.K., Gerrard, C.M., Gutierrez, A., Snape-Kennedy, L.M., Wilkinson, K.N., 2015. Luminescence dating of irrigation systems: Application to a qanat in Aragon, Spain. Quaternary Geochronology 30, 452-459.

Barker, G.W.W., Gilbertson D.D., Jones G.D.B., Mattingly, D.J., 1996. Farming the Desert. The UNESCO Libyan Valleys Archaeological Survey. Volume 1, Synthesis. UNESCO, Society for Libyan Studies, Paris/London.

Boucharlat, R., 2003. Water draining galleries in the Iron Age Oman Peninsula and the Iranian 'qanat'. In Potts, D.T., Al-Naboodah, H., Hellyer, P., (Eds.), Archaeology of the United Arab Emirates. Proceedings of the First International Conference on the Archaeology of the U.A.E., Trident Press, London, UK, 162-172.

Brooks, N., 2006. Cultural responses to aridity in the Middle Holocene and increased social complexity. Quaternary International, 151, 29-49.

Bullock, P., Fedoroff, N., Jongerius, A., Stoops, G., Tursina, T., Babel, U., 1985. Handbook for Soil Thin Section Description. Waine Research Publication, Albrighton.

Burns, S.J., Matter, A., 1995. Geochemistry of carbonate cements in surficial alluvial conglomerates and their paleoclimatic implications, Sultanate of Oman. Journal of Sedimentary Research A65, 170-177.

Capezzuoli, E., Gandin, A., Pedley, M., 2014. Decoding tufa and travertine (fresh water carbonates) in the sedimentary record: The state of the art. Sedimentology 61, 1-21.

Charbonnier, J, 2015. Groundwater management in Southeast Arabia from the Bronze Age to the Iron Age: a critical reassessment. Water History 7/1, 39-71.

Cheng, H., Edwards, R.L., Hoff, J., Gallup, C.D., Richards, D.A., Asmerom, Y., 2000. The half-lives of Uranium-234 and Thorium-230. Chemical Geology 169, 17-33.

Clark, I.D., Fontes, J.-C., 1990. Paleoclimatic reconstruction in northern Oman based on carbonates from hyperalkaline groundwaters. Quaternary Research 33, 320-336.

Cleuziou, S., Costantini, L., 1980. Premiers elements sur l'agricolture protohistorique de l'Arabie orientale. Paléorient 6, 255-261. 
Condoluci, C., Degli Esposti, M., Phillips, C., 2014. Iron age settlement patterns at Salūt, ca, 1300300 BC. Proceedings of the Seminar for Arabian Studies 44, 99-119.

Courty, M.-A., Goldberg, P., Macphail, R., 1989. Soil and Micromorphology in Archaeology. Cambridge University Press, Cambridge

Cremaschi, M., Pizzi, C., Valsecchi V., 2006. Water management and land use in the terramare and a possible climatic co-factor in their abandonment: The case study of the terramara of Poviglio Santa Rosa (northern Italy). Quaternary International 151, 87-98.

Cremaschi, M., Zerboni, A., 2009. Early to Middle Holocene landscape exploitation in a drying environment: Two case studies compared from the central Sahara (SW Fezzan, Libya). C. R. Geoscience 341, 689-702. doi:10.1016/j.crte.2009.05.001.

Cremaschi, M., Zerboni, A., Charpentier, V., Crassard, R., Isola, I., Regattieri, E., Zanchetta, G., 2015. Early Holocene climate changes and pre-Neolithic human occupations as recorded in the cavities of Jebel Qara (Dhofar, southern Sultanate of Oman). Quaternary International 382, 264-276. DOI: 10.1016/j.quaint.2014.12.058.

Cremaschi, M., Zerboni, A., Spötl, C., Felletti, F., 2010. The calcareous tufa in the Tadrart Acacus Mt. (SW Fezzan, Libya). An early Holocene palaeoclimate archive in the central Sahara. Palaeogeogr. Palaeoclimatol. Palaeoecol. 287, 81-94.

De Cardi, B., Collier, St., Doe, B., 1976, Excavations and survey in Oman, 1974-1975. Journal of Oman Studies 2, 101-188.

Degli Esposti, M., 2015. Two thousand years of settlement at Salut (ca. 2300-300BC). In: Avanzini, A., (Ed.), In the heart of Oman. The castle of Salut. (Ancient Oman, 1). L'«Erma» di Bretschneider, Roma, Italy, 55-66.

Degli Esposti, M., 2016. Excavations at the Early Bronze Age site «ST1» near Bisyah (Sultanate of Oman): notes on the architecture and material culture. In: Stucky, R.A., Kaelin, O., Mathys, H.-P., (Eds.), Proceedings of the $9^{\text {th }}$ International Congress on the Archaeology of the Ancient Near East. June 9-13, 2014, University of Basel, Vol. 3. Harrassowitz Verlag, Wiesbaden, Germany, 665-678.

Degli Esposti, M., Condoluci, C., Phillips, C., Tagliamonte, E., Sasso, M., 2018a. The Early Iron Age chronology in South East Arabia: a reassessment on the basis of Husn Salut excavations. In: Avanzini, A., Degli Esposti, M., (Eds.), Husn Salut and the Iron Age of South East Arabia. Excavations of the Italian Mission To Oman 2004-2014. Arabia Antica 15, L'Erma di Bretschneider, Roma, 371-382. 
Degli Esposti, M., Cremaschi, M., Perego, A., Zerboni, A., 2018b. Geographical and environmental setting. In: Avanzini, A., Degli Esposti, M., (Eds), Husn Salut and the Iron Age of South East Arabia. Excavations of the Italian Mission to Oman 2004-2014. Arabia Antica 15, L'Erma di Bretschneider, 19-31.

Desruelles, S., Fouache, E., Eddargach, W., Cammas, C., Wattez, J., Beuzen-Waller, T., Martin, C., Tengberg, M., Cable, C., Thornton, C., Murray, A., 2016, Evidence for early irrigation at Bat (Wadi Sharsah, northwestern Oman) before the advent of farming villages. Quaternary Science Reviews 150, 42-54.

Fairchild, I.J., Smith, C.L., Baker, A., Fuller, L., Spötl, C., Mattey, D., McDermott, F., E.I.M.F., 2006. Modification and preservation of environmental signals in speleothems. Earth-Science Reviews 75, 105-153.

FAO, 1987. Agroclimatological data for Asia. Plant Productivity and Protection Series, 25.

Fleitmann, D., Burns, S.J., Mangini, A., Mudelsee, M., Kramers, J., Villa, I., Neff, U., Al-Subbarye, A.A., Buettner, A., Hippler, D., Matter, A., 2007. Holocene ITCZ and Indian monsoon dynamics recorded in stalagmites from Oman and Yemen (Socotra). Quaternary Science Reviews 26, 170-188.

Fiorani Piacentini, V., 1985. Ardashir i Papakan and the wars against the Arabs: working hypothesis on the Sasanian hold of the Gulf. Proceedings of the Seminar for Arabian Studies $15,57-78$.

Frisia, S., Borsato, A., Fairchild, I.J., McDermott, F., Selmo, E.M., 2002. Aragonite-calcite relationships in speleothems (Grotte de Clamouse, France): environment, fabrics, and carbonate geochemistry. Journal of Sedimentary Research 72, 687-699.

Goldberg, P., Berna, F., 2010. Micromorphology and context. Quat. Int. 214, 56-62.

Goldberg, P., Macphail, R.I., 2006. Practical and Theoretical Geoarchaeology. Blackwell Publishing, Oxford.

Hastings, A., Humphries, J.H., Meadow, R.H., 1975. Oman in the Third Millennium BCE. Journal of Oman Studies 1, 9-55.

Hendy, C.H., 1971. The isotopic geochemistry of speleothems, I: the calculation of the effects of different modes of formation on the isotopic composition of speleothems and their applicability as palaeoclimatic indicators. Geochimica et Cosmochimica Acta 35, 801-824. 
Horvatincic, N., Krajcar-Bronic, I., Obelic, B., 2003. Differences in the ${ }^{14} \mathrm{C}$ age, $\delta^{13} \mathrm{C}$ and $\delta^{18} \mathrm{O}$ of Holocene tufa and speleothem in the Dinaric Karst. Palaeogeography, Palaeoclimatology, Palaeoecology 193, 139-157.

Humphries, J.H., 1974. Harvard Archaeology Survey in Oman: II - Some later prehistoric sites in the Sultanate of Oman. Proceedings of the Seminar for Arabian Studies 4, 49-77.

Jorgensen, D.G., Al-Tikiriti, W.Y., 2002. A hydrological and archaeological study of climate change in Al Ain, United Arab Emirates. Global and Planetary Change 35, 37-49.

Kennet, D., 2007. The decline of eastern Arabia in the Sasanian period. Arabian Archaeology and Epigraphy 18/1, 86-122.

Khan, M.F.K., Nawaz, M., 1987. Karez irrigation in Pakistan. In: Rahman, M., (Ed.), The Muslim world. Akademische Verlagsgesellschaft Wiesbaden, Germany, pp. 91-100.

Kühn, P., Pietsch, D., Gerlach, I., 2010. Archaeopedological analyses around a Neolithic hearth and the beginning of Sabaean irrigation in the oasis of Ma'rib (Ramlat as-Sab'atayn, Yemen). Journal of Archaeological Science 37, 1305-1310.

Kuper, R., Kröpelin, S., 2006. Climate-controlled Holocene occupation in the Sahara: motor of Africa's evolution. Science 313, 803-807.

Lightfoot, D., 1996. Syrian qanat Romani: history, ecology, abandonment. Journal of Arid Environments.

Lightfoot, D.R., 1997. Qanats in the Levant: Hydraulic Technology at the Periphery of Early Empires. Technology and Culture 38, 432-451.

Lightfoot, D.R., 2000. The origin and diffusion of qanats in Arabia: New evidence from the northern and southern Peninsula. The Geographical Journal 166, 215-226.

Madella, M., Fuller, D.Q., 2006. Palaeoecology and the Harappan Civilisation of South Asia: a reconsideration. Quaternary Science Reviews 25, 1283-1301.

Magee, P., 1996. The chronology of the southeast Arabian Iron Age. Arabian Archaeology and Epigraphy 7/2, 240-252.

Magee, P., 2014. The archaeology of prehistoric Arabia. Adaptation and Social Formation from the Neolithic to the Iron Age, Cambridge University Press, Cambridge, UK.

Manning, K., Timpson, A., 2014. The demographic response to Holocene climate change in the Sahara. Quat Sci Rev 101, 28-35.

Mattingly, D.J., 2003. The Archaeology of Fazzan: Vol. 1, Synthesis. Department of Antiquities, Tripoli, and Society for Libyan Studies, London. 
Mayewski, P.A., Rohling, E.E., Stager, J.C., Karlen, W.K., Maasch, K.A., Meeker, L.D., Meyerson, E.A., Gasse, F., Van Kreveld, S., Holmgren, K., Lee-Thorp, J., Rosqvist, G., Rack, F., Staubwasser, M., Schneider, R.R., Steig, E.J., 2004. Holocene climate variability. Quaternary Research 62, 243-255.

Murphy, C.P., 1986. Thin Section Preparation of Soils and Sediments. AB Academic Publishers, Berkhamsted, Herts.

Neff, U., Burns, S.J., Mangini, A., Mudelsee, M., Fleitmann, D., Matter, A., 2001. Strong coherence between solar variability and the monsoon in Oman between 9 and 6 ka ago. Nature 411, 290-293.

Oberlander, T.M., 1994. Rock varnish in deserts. In: Abrahams, A.D., Parsons, A.J., (Eds.), Geomorphology of Desert Environments. Chapman \& Hall, London, 107-119.

Orchard, J.J., Orchard, J.C., 2002. The Work of the Al-Hajar Project in Oman. Journal of Oman Studies 12, 227-234.

Orchard, J. C., Orchard, J.J., 2010. A 5000 Year Old Falaj in the Wadi Bahla, Oman. In: Matthiae, P., Pinnock, F., Nigro, L., Marchetti, N., (Eds.), Proceedings of the 6th International Congress on the Archaeology of the Ancient Near East 2, Harrassowitz Verlag, Wiesbaden, Germany 511524.

Orchard, J.C., Stanger, G., 1994. Third Millennium Oasis Towns and Environmental Constraints on Settlement in the Al-Hajar Region. Iraq 56, 63-100.

Nicoll, K., Sallam, E.S., 2017. Paleospring tufa deposition in the Kurkur Oasis region and implications for tributary integration with the River Nile in southern Egypt. Journal of African Earth Sciences 136, 239-251.

Pentecost, A., 2005. Travertine, 445 pp., Springer, Berlin.

Perego, A., Zerboni, A., Cremaschi, M., 2011. The geomorphological map of the Messak Settafet and Mellet (Central Sahara, SW Libya). Journal of Maps v2011, 464-475.

Phillips, C., Condoluci, C., Degli Esposti, M., 2010. Archaeological survey in Wadi Bahla (Sultanate of Oman): an Iron Age site on Jebel al-Agma, near Bisyah. Egitto e Vicino Oriente 33, 151168.

Potts, D. T., 1985. From Qâde to Mazûn: four notes on Oman, c. 700BC to 700 AD. Journal of Oman Studies 8/1, 81-95.

Potts, D. T., 1990. The Arabian Gulf in antiquity, Vol. 1: From Prehistory to the Fall of the Achaemenid Empire. Oxford University Press, Oxford, UK. 
Potts, D. T., 1994a. Contributions to the agrarian history of Eastern Arabia I. Implements and cultivars. Arabian Archaeology and Epigraphy 5/3, 158-168.

Potts, D. T., 1994b. Contributions to the agrarian history of Eastern Arabia II. The cultivars. Arabian Archaeology and Epigraphy 5/4, 236-275.

Reimer, P.J., Bard, E., Bayliss, A., Beck, J.W., Blackwell, P.G., Bronk Ramsey, C., Buck, C.E., Cheng, H., Edwards, R.L., Friedrich, M., Grootes, P.M., Guilderson, T.P., Haflidason, H., Hajdas, I., Hatt_e, C., Heaton, T.J., Hoffmann, D.L., Hogg, A.G., Hughen, K.A., Kaiser, K.F., Kromer, B., Manning, S.W., Niu, M., Reimer, R.W., Richards, D.A., Scott, E.M., Southon, J.R., Staff, R.A., Turney, C.S.M., Plicht, J., 2013. IntCal13 and Marine13 radiocarbon age calibration curves 050,000 years cal BP. Radiocarbon 55, 1869-1887.

Remmington, G., 2018. Transforming tradition: The aflaj and changing role of traditional knowledge systems for collective water management. Journal of Arid Environments 151, 134-140. dx.doi.org/10.1016/j.jaridenv.2017.10.003.

Schreiber, J., 2007. Transformationsprozesse in Oasensiedlungen Omans. Die vorislamische Zeit am Beispiel von Izki, Nizwa und dem Jebel Akhdar. Unpublished PhD Dissertation, LMU München.

Siebert, S., Nagieb, M., Buerkert, A., 2007. Climate and irrigation water use of a mountain oasis in northern Oman. Agricultural Water Management 89, 1-14.

Smith, J.R., Giegengack, R., Schwarcz, H.P., 2004. Constraints on Pleistocene pluvial climates through stable-isotope analysis of fossil-spring tufas and associated gastropods, Kharga Oasis, Egypt. Palaeogeography, Palaeoclimatology, Palaeoecology 206, 157-175.

Stephen, A.L., Jenkin, G.R.T., Styles, M.T., Smith. D.J., Naden, J., Boyce, M.J., Leng, M.J., Millar, I.L., 2013. Tracing carbon: natural mineral carbonation and the incorporation of atmospheric vs. recycled $\mathrm{CO}_{2}$. Energy Procedia 37, 5897-5904.

Stoops, G., 2003. Guidelines for Analysis and Description of Soil and Regolith Thin Sections. Soil Science Society of America, Madison, WI.

Stoops, G., Marcellino, V., Mees, F., 2010. Interpretation of Micromorphological Features of Soil and Regoliths. Elsevier, Amsterdam.

Stiros, S.C., 2006. Accurate measurements with primitive instruments: the "paradox" in the qanat design. Journal of Archaeological Science 33, 1058-1064.

Wedepohl, K.H., 1995. The composition of the continental crust. Geochimica et Cosmochimica Acta 59, 1217-1232. 
Weiss, H., 1997. Late third millennium abrupt climate change and social collapse in West Asia and Egypt. In: Dalfes, H.N., Kukla, G., Weiss, H. (Eds.), Third Millennium BC Climate Change and Old World Collapse, NATO ASI Series, vol. I 49. Springer, Berlin, Heidelberg, pp. 711723.

Weyhenmeyer, C.E., Burns, S.J., Waber, H.N., Aeschbach-Hertig, W., Kipfer, R., Loosli, H.H., Matter, A., 2000. Cool glacial temperatures and changes in moisture source recorded in Oman groundwaters. Science 287, 842-845.

Weyhenmeyer, C.E., Burns, S.J., Waber, H.N., Macumber, P.G., Matter, A., 2002. Isotope study of moisture sources, recharge areas, and groundwater flow paths within the eastern Batinah coastal plain, Sultanate of Oman. Water Resources Research 38, 1184.

Whitcomb, D.S., 1975. The archaeology of Oman: a preliminary discussion of the Islamic periods. Journal of Oman Studies 1, 123-158.

Wilkinson, J.C., 1975. The Julanda of Oman. Journal of Oman Studies 1, 97-108.

Wilkinson, J.C., 1977. Water and tribal settlement in south-east Arabia. A study of the aflāj of Oman. Clarendon Press, Oxford, UK.

Wilkinson, J.C., 1983. The origins of the aflaj of Oman. Journal of Oman Studies 6, 177-194.

Wilkinson, T.J., 2003. Archaeological Landscapes of the Near East. University of Arizona Press.

Yule, P., 2008. Sasanian Presence and Late Iron Age Samad in Central Oman, some Corrections. In: Schiettecatte, J., Robin, C., (Eds.), L'Arabie à la veille de l'Islam. Bilan Clinique, De Boccard, Paris, France, 69-90.

Zanchetta, G., Bini, M., Cremaschi, M., Magny, M., Sadori, L., 2013. The transition from natural to anthropogenic-dominated environmental change in Italy and the surrounding regions since the Neolithic: An introduction. Quaternary International 303, 1-9.

Zerboni, A., Biagetti, S., Lancelotti, C., Madella, M., 2016. The end of the Holocene Humid Period in the central Sahara and Thar deserts: societal collapses or new opportunities? PAGES Magazine 24, 60-61. DOI: 10.22498/pages.24.2.60 